\title{
A Critical Role for Sorting Nexin 1 in the Trafficking of Metabotropic Glutamate Receptors
}

\author{
Rohan Sharma, Ravinder Gulia, and Samarjit Bhattacharyya \\ Department of Biological Sciences, Indian Institute of Science Education and Research, Mohali, Knowledge City, 140306, Punjab, India
}

Group I metabotropic glutamate receptors (mGluRs) function as modulators of neuronal physiology and they have also been implicated in various neuropsychiatric disorders. Trafficking of mGluRs plays important roles in controlling the precise localization of these receptors at specific region of the cell, as well as it regulates the activity of these receptors. Despite this obvious significance, we know very little about the cellular machineries that control the trafficking of these receptors in the CNS. Sorting nexin 1 (SNX1) has been shown to regulate the endosomal sorting of few cell surface receptors either to lysosomes where they are downregulated or back to the cell surface. Using "molecular replacement" approach in hippocampal neurons derived from mice of both sexes, we show here that SNX1 plays critical role in the trafficking of mGluR1, a member of the group I mGluR family. Overexpression of dominant-negative SNX1 or knockdown of endogenous SNX1 resulted in the rapid recycling of the receptor. Importantly, recycling via the rapid recycling route, did not allow the resensitization of the receptors. Our data suggest that both, N-terminal and C-terminal region of SNX1 play critical role in the normal trafficking of the receptor. In addition, we also show here that SNX1 regulates the trafficking of mGluR1 through the interaction with Hrs (hepatocyte growth factor-regulated tyrosine kinase substrate), a protein that has been implicated in both signaling and vesicular trafficking. Thus, these studies reveal a mechanistic role of SNX1 in the trafficking of group I mGluRs and its physiological implications.

Key words: GPCR; metabotropic glutamate receptors; neurotransmitter receptors; recycling; SNX1; trafficking

Significance Statement

Group I mGluRs are activated by the neurotransmitter glutamate in the CNS, and play various important roles in the brain. Similar to many other receptors, trafficking plays crucial roles in controlling the precise localization as well as activity of these receptors. Despite this obvious significance very little is known about the cellular machineries that control the trafficking of these receptors. We demonstrate here, that SNX1 plays a critical role in the trafficking of mGluR1, a member of the group I mGluR family. SNX1-mediated trafficking is critical for the resensitization of the receptor. SNX1 controls the trafficking of the receptor through the interaction with another protein, Hrs. The results suggest a role for SNX1 in the regulation of group I mGluRs.

\section{Introduction}

Glutamate is a major excitatory neurotransmitter in the CNS, which acts via two types of receptors, viz., ionotropic and metabotropic glutamate receptors (mGluRs; Pin and Duvoisin, 1995; Dhami and Ferguson, 2006; Bhattacharyya, 2016). mGluRs

\footnotetext{
Received Feb. 20, 2018; revised July 22, 2018; accepted Aug. 16, 2018.

Author contributions: R.S., R.G., and S.B. edited the paper; S.B. wrote the first draft of the paper. R.S., R.G., and S.B. designed research; R.S. and R.G. performed research; R.S., R.G., and S.B. analyzed data; R.S., R.G., and S.B. wrote the paper.

This work was supported by the Indian Institute of Science Education and Research, Mohali, University Grants Commission fellowships to R.S. and R.G. We thank Dr. Kathrine Roche (NIH) for the generous gift of the myc-mGluR1 construct, Dr. Mark von Zastrow (University of California, San Francisco, CA) for the myc-Hrs construct, and members of our laboratory for valuable input.

The authors declare no competing financial interests.

Correspondence should be addressed to Dr. Samarjit Bhattacharyya, Department of Biological Sciences, Indian Institute of Science Education and Research, Mohali, Knowledge city, Sector-81, SAS Nagar, P0 140306, Punjab, India. E-mail: samarjit@iisermohali.ac.in.

DOI:10.1523/JNEUROSCI.0454-18.2018

Copyright $\odot 2018$ the authors $\quad 0270-6474 / 18 / 388605-16 \$ 15.00 / 0$
}

have been classified into three groups (Nakanishi, 1994; Pin and Duvoisin, 1995; Conn and Pin, 1997). Group I mGluRs are comprised of mGluR1, mGluR5, and they are canonically linked to the $\mathrm{G}_{\alpha \mathrm{q} / 11}$ heterotrimeric G-proteins (Conn and Pin, 1997; Kim et al., 2008). These receptors have been implicated in various forms of synaptic plasticity, as well as in various neuropsychiatric disorders like Fragile-X syndrome, autism etc. (Huber et al., 2002; Bear et al., 2004; Koekkoek et al., 2005; Anwyl, 2006; Dölen et al., 2007; Citri and Malenka, 2008; Gladding et al., 2009; Michalon et al., 2012). Similar to many other GPCRs, trafficking of these receptors is a tightly regulated process controlling the spatiotemporal localization and activity of these receptors. Subsequent to the activation by the ligand, these receptors undergo "desensitization", which is a negative feedback mechanism that protects the receptor from chronic overstimulation (Francesconi and Duvoisin, 2000; Sallese et al., 2000; Dale et al., 2002; Dhami and Ferguson, 2006; Bhattacharyya, 2016). Following that, they internalize and recycle back to the cell surface, suggesting a mech- 
anism for "resensitization" of these receptors (Mundell et al., 2001, 2004; Choi et al., 2011; Pandey et al., 2014; Mahato et al., 2015; Gulia et al., 2017). Despite the obvious significance of trafficking of mGluRs, the molecular mechanisms underlying these processes are not well understood.

Sorting nexins (SNXs) are a group of proteins defined by the presence of phox homology (PX) domain. Among the members of this group, SNX1 regulates endosome to trans-Golgi network (TGN) retrograde transport of large number of cargos (Worby and Dixon, 2002; Wassmer et al., 2007, 2009). However, various reports have suggested that SNX1 could also control the trafficking and sorting of some receptors through other pathways (Worby and Dixon, 2002). For example, SNX1 has been shown to regulate the lysosomal degradation of the protease activated receptor, epidermal growth factor receptor (EGFR), and recycling of P2Y ${ }_{1}$ receptor (Kurten et al., 1996; Wang et al., 2002; Gullapalli et al., 2004; Nisar et al., 2010). SNX1 has also been shown to interact in vitro with the cytoplasmic tails of mGluR1 and mGluR5 (Heydorn et al., 2004). In light of all the above results, we investigated the role of SNX1, if any, in the trafficking of group I mGluRs in primary hippocampal neurons.

We studied the role of SNX1 in ligand-mediated trafficking of mGluR1 using a "molecular replacement" approach that allows simultaneous shRNA-mediated acute knockdown of endogenous SNX1 and expression of various forms of recombinant SNX1 in primary hippocampal neurons (Bhattacharyya et al., 2009; Citri et al., 2010). This approach has two important advantages. First, developmental compensatory adaptations that may occur during synaptogenesis and synapse maturation as a result of the loss of endogenous SNX1 are minimized. Second, the function of heterologous constructs can be studied without the necessity of a dominant effect as required by a standard overexpression approach. We show here that SNX1 plays a critical role in the trafficking of mGluR1. We observed that overexpression of dominant-negative SNX1 or knockdown of endogenous SNX1 led to the rapid recycling of the receptor. Both, $\mathrm{N}$-terminal region and C-terminal region of SNX1 were critical for the normal trafficking of the receptor. Importantly, we also show here that SNX1 regulates the trafficking of mGluR1 through the interaction with Hrs (hepatocyte growth factor-regulated tyrosine kinase substrate), a protein that has been implicated in both signaling and vesicular trafficking (Komada and Kitamura, 1995; Komada et al., 1997; Kwong et al., 2000). Knockdown of Hrs also resulted in the rapid recycling of mGluR1. Finally, we show, that rapid recycling of the receptor in SNX1 knockdown cells did not allow the resensitization of the receptor.

\section{Materials and Methods}

Materials

The myc-mGluR1 construct in which the myc epitope was tagged at the $\mathrm{N}$-terminus of the full-length mGluR1 was a generous gift from Kathrine Roche (NIH). The full-length mouse SNX1 was purchased from Origene. The full-length myc-Hrs was a gift from Mark von Zastrow (University of California, San Francisco). HEK293T cells were purchased from NCCS Pune, India. Cell culture reagents were purchased from Invitrogen. Cycloheximide, okadaic acid, FK-506, FUDR (floxuridine), paraformaldehyde (PFA), poly-D-lysine, Fluoromount aqueous mounting medium were purchased from Sigma-Aldrich. Protein $G$ beads were from GenScript. R,S-DHPG [(RS)-3,5-dihydroxyphenylglycine], APV, and DNQX (6,7-dinitroquinoxaline-2,3-dione) were obtained from Tocris Bioscience. Tetrodotoxin (TTX) was purchased from Adooq Biosciences. Fine chemicals were obtained from Life Technologies and Merck. The primary antibodies were purchased from following companies: antimyc antibody from Abcam, anti-HA antibody from Roche, anti-phos- pho-p44/42 MAPK (ERK1/2) antibody from Cell Signaling Technology, anti-p44/42 MAPK (ERK1/2) antibody from Cell Signaling Technology, anti-GFP antibody from Life Technologies, anti-Hrs antibody from Enzo Life Sciences, anti-SNX1 antibody from Proteintech, anti- $\beta$ actin antibody from Santa Cruz Biotechnology, and anti-GluA1 antibody from Calbiochem. All secondary antibodies were purchased from Invitrogen. ECL Western blot detection kit was obtained from GE Healthcare. ONTARGET plus SMARTpool siRNA against SNX1 and Hrs were obtained from ThermoFisher Scientific Dharmacon.

\section{Construct preparation}

The shRNA against SNX1 (shSNX1) was cloned in a multipromoter vector under the $\mathrm{H} 1$ promoter targeting SNX1 sequence TGAATCATC CCACCATGTT. eGFP expression, which was under IRES, was used to identify transfected cells. The replacement constructs were cloned under the ubiquitin promoter of the vector containing shSNX1. These replacement constructs include shSNX1:HA-SNX1 (full-length SNX1), shSNX1:HA-SNX1 $\Delta \mathrm{N}$ ( presence of amino acids 265-521 of SNX1), shSNX1: HA-SNX1 $\Delta \mathrm{C}$ (presence of amino acids 1-271 of SNX1), shSNX1:HASNX1 $\Delta \mathrm{H} 1$ (H1 domain of SNX1, i.e., amino acids 308-341 were deleted), shSNX1:HA-SNX1 $\Delta \mathrm{H} 2$ (H2 domain of SNX1 i.e., amino acids 355-387 were deleted), shSNX1:HA-SNX1 $\Delta \mathrm{H} 3$ (H3 domain of SNX1, i.e., amino acids $439-475$ were deleted). For generation of the above replacement constructs, silent mutations were introduced in the SNX1 target region of shSNX1. Silent mutations in the shSNX1 binding region in the replacement SNX1 prevented the knockdown of the replacement constructs by shSNX1 but simultaneously the endogenous SNX1 was downregulated. All replacement constructs were tagged with the HA epitope at the $\mathrm{N}$-terminus of the protein.

\section{Dissociated hippocampal neuron cultures}

Primary hippocampal neuron cultures were prepared from P0 C57BL/6 mouse pups of both sexes, as described previously with minor changes (Mahato et al., 2015; Gulia et al., 2017). Briefly, hippocampi were obtained from $\mathrm{P} 0$ mouse pups and subsequently, tissue was dissociated by papain treatment. Cells were then plated on poly-D-lysine in sodium borate-coated coverslips $(50 \mu \mathrm{g} / \mathrm{ml}$ poly-D-lysine $+0.1 \mathrm{M}$ sodium borate) at a density of $\sim 150,000$ cells per $12 \mathrm{~mm}$ well in a 24 -well plate. Cultures were maintained in neurobasal media with $0.5 \mathrm{~mm}$ glutamine and B27 supplement. Glial growth was inhibited by adding FUDR on the fourth day of culture.

\section{HEK293T cell culture and transfection}

HEK293T cells were cultured in DMEM supplemented with 10\% FBS, antibiotic-antimycotic mix at $37^{\circ} \mathrm{C}$ and $5 \% \mathrm{CO}_{2}$. Transfection of the cells was performed on $60 \mathrm{~mm}$ dishes coated with $50 \mu \mathrm{g} / \mathrm{ml}$ poly-D-lysine by mixing $2 \mu \mathrm{g}$ of DNA with $10 \mu \mathrm{g}$ of Lipofectamine 2000 in $1 \mathrm{ml}$ of OptiMEM. Experiments in HEK293T cells were performed $24 \mathrm{~h}$ posttransfection.

\section{Transfection in primary hippocampal neurons}

Primary hippocampal neurons were transfected with myc-mGluR1, shSNX1 and various SNX1 replacement constructs at 7-9 din vitro (DIV) using calcium phosphate and all the experiments were performed when the cells were at 12-15 DIV. For knockdown of SNX1 or Hrs with siRNA, ON-TARGET plus SMARTpool siRNA against SNX1 or Hrs and scrambled siRNA were cotransfected with myc-mGluR1 cDNA in primary hippocampal neurons at 8-9 DIV using Lipofectamine 2000 following the manufacturer's instructions and experiments were performed in cells at 12-14 DIV.

\section{Experimental design and statistical analyses}

Endocytosis and recycling assay. The myc-mGluR1 cDNA was cotransfected with either shSNX1 or shSNX1 containing SNX1 replacement constructs in primary hippocampal neurons. Experiments were performed 4-6 d after transfection. Live cells were incubated with mouse anti-myc primary antibody (1:250) for $20 \mathrm{~min}$ at $37^{\circ} \mathrm{C}$. Subsequently, cells were treated with $100 \mu \mathrm{M}$ R,S-DHPG, which is a specific agonist of group I mGluRs, for $5 \mathrm{~min}$ followed by incubation of the cells at $37^{\circ} \mathrm{C}$ for various time periods in plain neurobasal media in the absence of the 
ligand. Cells were then fixed without permeabilization using ice-cold $4 \%$ PFA for $15 \mathrm{~min}$ on ice. Surface localized receptors were labeled with saturating concentration of goat anti-mouse AlexaFluor 568-conjugated secondary antibody $(1: 100)$ for $1 \mathrm{~h}$ at $37^{\circ} \mathrm{C}$. Cells were then permeabilized with $0.1 \%$ Triton $\mathrm{X}-100$ for $30 \mathrm{~min}$ at room temperature. The internalized receptors were then labeled by the application of goat anti-mouse AlexaFluor 647 -conjugated secondary antibody $(1: 800)$ for $1 \mathrm{~h}$ at $37^{\circ} \mathrm{C}$. Subsequently, the cotransfected shRNA constructs containing GFP and HA-tagged replacement constructs were stained with rabbit anti-GFP antibody (1:500) and rat anti-HA antibody (1:500), respectively, overnight at $4^{\circ} \mathrm{C}$. After that, they were stained with appropriate AlexaFluor 488-conjugated secondary antibodies. The coverslips were mounted on glass slides and scanned under the confocal microscope. To ensure that the AlexaFluor 647-conjugated secondary antibody did not label any detectable surface receptors in our assays, we performed control experiments to determine the saturating concentration of the first secondary antibody similar to that we have described in our earlier studies (Trivedi and Bhattacharyya, 2012; Pandey et al., 2014; Mahato et al., 2015; Gulia et al., 2017). The control experiments suggested that in our assays, AlexaFluor 647-conjugated secondary antibody did not label any detectable amount of surface receptors and thus it stained the internalized receptors only (data not shown).

The experiments involving recycling of the receptor were performed by initially labeling the myc-mGluR 1 expressing live primary hippocampal neurons with anti-myc primary antibody and inducing the internalization of the receptor by the application of $100 \mu \mathrm{M}$ R,S-DHPG for $5 \mathrm{~min}$ using identical protocol as described above. Subsequently, cells were incubated in plain neurobasal medium for different time periods in absence of the ligand. After specific time point, cells were fixed and surface and internalized receptors were labeled by Alexa Fluor 568-conjugated and Alexa Fluor 647-conjugated secondary antibodies respectively, using the same protocol as described for the endocytosis assay.

To study the ability of the mGluRs recycled via either the normal or rapid recycling route, in the induction of the AMPAR endocytosis, we performed the mGluR-mediated AMPAR endocytosis assay using our previous protocol (Gulia et al., 2017). Both control cells and shSNX1 transfected cells were first treated with appropriate mixtures of antagonists: $1 \mu \mathrm{M}$ TTX (presynaptic release blocker), $20 \mu \mathrm{M}$ DNQX (antagonist for AMPARs), and $50 \mu \mathrm{M}$ APV (antagonist for NMDARs) for $30 \mathrm{~min}$. Subsequently, in control cells, $100 \mu \mathrm{M}$ R,S-DHPG was applied for $5 \mathrm{~min}$ to induce the internalization of group I mGluRs. Receptors were then allowed to recycle back to the cell surface in $2.5 \mathrm{~h}$ following the method described above. In another set of control cells, the recycling of the receptors was inhibited by the application of $5 \mathrm{~nm}$ okadaic acid and $1 \mu \mathrm{M}$ FK-506. Similarly, in shSNX1 transfected cells as well, $100 \mu \mathrm{m}$ R,S-DHPG was applied for $5 \mathrm{~min}$ to induce the internalization of group I mGluRs and receptors were allowed to recycle back in $30 \mathrm{~min}$ following the method described in the previous paragraph. Subsequent to the appropriate recycling time of the receptors $(2.5 \mathrm{~h}$ for control cells and $30 \mathrm{~min}$ for shSNX1 transfected cells), surface GluA1-containing AMPARs were labeled in live neurons by $15 \mathrm{~min}$ incubation at $37^{\circ} \mathrm{C}$ with a rabbit polyclonal antibody directed against the N-terminus of the GluAl subunit (1:20). To measure the AMPAR endocytosis induced by the mGluRs, when they were initially present at the cell surface in both control cells and shSNX1 transfected cells, cells were treated with antagonists and GluA1-containing receptors were labeled with the antibody in live cells as described above. In all the conditions, subsequent to the labeling of GluA1-containing receptors, $100 \mu \mathrm{M}$ R,S-DHPG was applied for $5 \mathrm{~min}$. The agonist was removed and cells were further incubated in the presence of the drugs for a total of $15 \mathrm{~min}$ at $37^{\circ} \mathrm{C}$. Cells were fixed at the end of the respective time periods in 4\% PFA for 15 min on ice without permeabilization and surface GluA1-containing receptors were visualized by using saturating amount of goat anti-rabbit AlexaFluor 568-conjugated secondary antibody (1:100) followed by permeabilization of cells with $0.1 \%$ Triton X-100 for $30 \mathrm{~min}$ at room temperature. The internalized GluA1containing receptors were then stained with goat anti-rabbit AlexaFluor 647 -conjugated secondary antibody (1:750). Again, to make sure that the AlexaFluor 647-conjugated secondary antibody did not label any detectable surface receptors in our assays, we determined the saturating con- centration of the first secondary antibody through a control experiment similar to that we have described in our earlier studies (Bhattacharyya et al., 2009; Citri et al., 2010; Gulia et al., 2017).

Immunoprecipitation and Western blot analysis. Knockdown of endogenous SNX1 and Hrs was studied by transfecting primary neurons two times with either siRNA against SNX1/Hrs (ON-TARGET plus SMARTpool) or scrambled siRNA (si-control; Dharmacon, ThermoFisher Scientific). Seventy-two hours post-transfection neurons were lysed in RIPA lysis buffer having protease inhibitor cocktail. The samples were then boiled in Laemmli sample buffer for $10 \mathrm{~min}$ and ran in SDSPAGE by loading an equal amount of protein in each lane. Subsequently, they were transferred to the PVDF membrane and blocked with 5\% skim milk in $0.05 \%$ PBST for $2 \mathrm{~h}$ at room temperature. The membrane was then incubated with either anti-SNX1 rabbit polyclonal antibody (1: 1000; for SNX1 staining) or anti-Hrs mouse monoclonal antibody (1: 1000; for Hrs staining) and anti $\beta$-actin $(1: 1000)$ antibody in $4^{\circ} \mathrm{C}$ overnight. Membranes were washed and incubated in horseradish peroxidase-conjugated secondary antibodies for $45 \mathrm{~min}$ at room temperature. Blots were developed using ECL Western detection kit and images were acquired in ImageQuant LAS 4000. For the detection of shRNAmediated knockdown of endogenous SNX1 and expression of replacement constructs, the Western blots were performed in the similar manner as described above by using anti-SNX1 rabbit polyclonal antibody (1:1000) and anti-HA rat monoclonal antibody (1:1000). $\beta$-actin was used as a loading control.

To check for the effect of the deletion of $\mathrm{H} 1, \mathrm{H} 2$, and $\mathrm{H} 3$ domains of SNX1 on the interaction of SNX1 with Hrs, HEK293T cells were plated on the $60 \mathrm{~mm}$ culture dish. Cotransfection of HA-tagged full-length SNX1 (shSNX1:SNX1) and mutants of SNX1 (shSNX1:SNX1 $\mathrm{H} 1$, shSNX1:SNX1 $\mathrm{H} 2$, shSNX1:SNX1 $\Delta \mathrm{H} 3$ ) with myc-tagged Hrs was performed next day. Twenty-four hours post-transfection, cells were washed with ice-cold PBS and lysed using TAP lysis buffer (20 mm Tris, pH 8.0, $150 \mathrm{~mm} \mathrm{NaCl}, 0.5 \% \mathrm{NP}-40,1 \mathrm{~mm} \mathrm{MgCl}, 1 \mathrm{~mm} \mathrm{Na} \mathrm{VO}_{4}, 1 \times$ protease inhibitor cocktail). The lysate was centrifuged at $16,000 \mathrm{rpm}$ for $15 \mathrm{~min}$. Then $50 \mu$ l of supernatant was collected as input. Immunoprecipitation was done using HA antibody bound protein-G beads. The samples were then subjected to SDS-PAGE electrophoresis followed by Western blotting in a similar way described earlier. The immunoblotting of SNX1 mutants and Hrs protein was performed using anti-SNX1 antibody (1: $1000)$ and anti-myc antibody (1:1000), respectively.

The ability of the rapidly recycled mGluRs to upregulate the phosphorylation of ERK1/2 was investigated by transfecting the primary hippocampal neurons with shSNX1. Both control cells and shSNX1 transfected cells were pre-incubated with $100 \mu \mathrm{g} / \mathrm{ml}$ cycloheximide for $5 \mathrm{~h}$ to inhibit the synthesis of new receptors. Subsequently, $100 \mu \mathrm{M}$ R,SDHPG was applied for $5 \mathrm{~min}$ in both control cells and shSNX1 transfected cells to initiate the endocytosis of mGluRs and they were allowed to recycle back to the cell surface, in absence of the ligand, in $2.5 \mathrm{~h}$ (in case of control cells) and $30 \mathrm{~min}$ (in case of shSNX1 transfected cells). Subsequently, $100 \mu \mathrm{M}$ R,S-DHPG was again applied for $5 \mathrm{~min}$. Cells were lysed and samples were run in SDS-PAGE followed by Western blotting following the similar protocol described earlier. The extent of upregulation of ERK1/2 phosphorylation by the mGluRs, when they were initially present at the cell surface in both control cells and shSNX1 transfected cells were measured by activating the receptors with $100 \mu \mathrm{M}$ R,S-DHPG for $5 \mathrm{~min}$, followed by Western blotting. The immunoblotting of phospho-ERK1/2 and total ERK1/2 was performed using anti-phosphop44/42 MAPK (ERK1/2) antibody (1:1000) and anti-p44/42 MAPK (ERK1/2) antibody (1:1000), respectively.

Image acquisition and analysis. Cells were imaged in Zeiss LSM 780 confocal laser scanning microscope using a $63 \times$ oil-immersion objective $(\mathrm{NA}=1.4)$. In each experiment, $40-50$ primary hippocampal neurons were imaged and each experiment was repeated at least three times. Images from all the conditions in a particular experiment were obtained using identical parameters. All the analyses procedures have been described in our previous studies (Trivedi and Bhattacharyya, 2012; Pandey et al., 2014; Mahato et al., 2015; Gulia et al., 2017). Briefly, we used raw images for all analyses and quantitation was done using ImageJ software (NIH; Schneider et al., 2012). Raw images were maximally projected and 
thresholded using identical values for a particular experiment. We subsequently measured the thresholded areas occupied by the fluorescence of the labeled surface and internalized receptors. The internalization index was then calculated by dividing the value contributed by the internal fluorescence with the value contributed by the total fluorescence (surface + internal). These values were then normalized with respect to their controls. To measure the surface receptors in all our assays, surface fluorescence was divided by the cell area, which was determined by measuring background fluorescence using a low threshold level. These values were then normalized to the average surface fluorescence of control cells. All data represent dendritic values of primary hippocampal neurons, which were defined by the area $10 \mu \mathrm{m}$ away from the soma. The quantitation of all the experiments has been represented as a combination of results from all three repeats of that particular experiment. The raw images were processed in Adobe Photoshop software using identical values of brightness and contrast to obtain the representative images. All the Western blots and immunoprecipitation experiments were also quantified using ImageJ software.

\section{Statistical analysis}

For each experiment 40-50 primary hippocampal neurons were imaged and each experiment was repeated three times. Data are presented as mean \pm SEM. Experimental group results were compared with each other using Student's $t$ test or one-way ANOVA followed by Tukey's post-test. $p>0.05$ was considered as nonsignificant.

\section{Results}

\section{SNX1 modulates the recycling of mGluR1}

Endocytosis of the receptor from the cell surface subsequent to its activation is critical for the regulation of GPCR activity. Subsequent to the internalization, GPCRs can have various subcellular fates. Some GPCRs recycle back to the cell surface, whereas others enter the lysosome following endocytosis for degradation (Drake et al., 2006). Similar to many other GPCRs, mGluR1 also undergoes rapid internalization following ligand exposure (Iacovelli et al., 2003; Pandey et al., 2014; Gulia et al., 2017). Subsequently, the receptor recycles back to the cell surface (Pandey et al., 2014). The cellular and molecular mechanisms that govern mGluR1 recycling are poorly understood. To investigate whether SNX1 could play any role in the trafficking of group I mGluRs, we studied the ligand-induced trafficking of myc-mGluR1 in presence of SNX1 C-terminus coiled-coil domain that functions in a dominantnegative manner. SNX1 C-terminus encodes a coiled-coil domain (SNX1-CC) that assembles with endogenous SNX1 to function as a dominant-negative (Wang et al., 2002). We initially checked for the effect of SNX1-CC overexpression on the surface expression of myc-mGluR1. Overexpression of SNX1-CC had no effect on the surface expression of myc-mGluR1 in primary hippocampal neurons (control: $1 \pm 0.04$; SNX1-CC: $1 \pm 0.05 ; p=$ 0.996 between control and SNX1-CC, unpaired $t$ test; Fig. $1 A, B)$. To investigate whether the dominant-negative SNX1 plays any role in the trafficking of myc-mGluR1, primary hippocampal neurons were cotransfected with myc-mGluR1 and SNX1-CC constructs. Live cells expressing myc-mGluR1 were stained with anti-myc primary antibody. Subsequent application of $100 \mu \mathrm{M}$ R,S-DHPG, which acts as an agonist of mGluR1, led to the internalization of myc-mGluR1 at $30 \mathrm{~min}$ in control cells, whereas cells expressing SNX1-CC did not show significant internalized receptors on $100 \mu \mathrm{M}$ R,S-DHPG application at $30 \mathrm{~min}$ time point and most of the receptors were observed to be localized at the cell surface (control: $1 \pm 0.09$; control + DHPG: $2.3 \pm 0.16$; SNX1CC: $1 \pm 0.07$; SNX1-CC + DHPG: $1.1 \pm 0.1 ; p=1.105 \times 10^{-9}$ between control and control + DHPG; $p=0.585$ between SNX1-CC and SNX1-CC + DHPG; one-way ANOVA followed by Tukey's post-test; Fig. $1 C, D)$. We chose $30 \mathrm{~min}$ as the time point since our previous study suggested that R,S-DHPG-mediated internalization of myc-mGluR1 reached maximum level at 30 min postligand application (Pandey et al., 2014). These results suggest that expression of dominant-negative SNX1 either inhibits the ligandmediated internalization of myc-mGluR1 or the receptor recycles back faster to the cell surface in $30 \mathrm{~min}$ in presence of SNX1-CC.

To determine whether overexpression of SNX1-CC led to the inhibition in the R,S-DHPG-mediated internalization of mycmGluR 1 or it resulted in the rapid recycling of the receptor to the cell surface, we performed time course of endocytosis experiment. Control cells expressing myc-mGluR1 were treated with anti-myc primary antibody. Subsequently, application of $100 \mu \mathrm{M}$ $\mathrm{R}, \mathrm{S}-\mathrm{DHPG}$ led to the rapid internalization of the receptor and the amount of myc-mGluR1 internalization increased over time till $30 \mathrm{~min}$ post-ligand application (untreated: $1 \pm 0.07 ; 5 \mathrm{~min}$ : $1.55 \pm 0.07 ; 15 \mathrm{~min}: 1.78 \pm 0.09 ; 30 \mathrm{~min}: 2.46 \pm 0.11 ; p=$ $9.034 \times 10^{-7}$ between untreated and $5 \mathrm{~min} ; p=3.232 \times 10^{-9}$ between untreated and $15 \mathrm{~min} ; p=1.374 \times 10^{-18}$ between untreated and $30 \mathrm{~min}$; one-way ANOVA followed by Tukey's posttest; Fig. $1 E, F)$. Quantitation of the receptors present at the cell surface also showed corresponding decrease in the receptor level from the cell surface on application of $100 \mu \mathrm{M}$ R,S-DHPG over time (untreated: $1 \pm 0.05 ; 5 \mathrm{~min}: 0.82 \pm 0.07 ; 15 \mathrm{~min}: 0.59 \pm$ 0.05 ; 30 min: $0.47 \pm 0.05 ; p=0.034$ between untreated and 5 $\min ; p=3.478 \times 10^{-7}$ between untreated and $15 \mathrm{~min} ; p=$ $5.072 \times 10^{-10}$ between untreated and $30 \mathrm{~min}$; one-way ANOVA followed by Tukey's post-test; Fig. 1G). Importantly, in SNX1CC-expressing cells myc-mGluR1 internalized on application of $100 \mu \mathrm{M}$ R,S-DHPG, but recycled back to the cell surface at $30 \mathrm{~min}$ (untreated: $1 \pm 0.07 ; 5 \mathrm{~min}: 2.38 \pm 0.08 ; 15 \mathrm{~min}: 1.93 \pm 0.1 ; 30$ min: $1 \pm 0.08 ; p=1.428 \times 10^{-20}$ between untreated and $5 \mathrm{~min}$; $p=1.592 \times 10^{-10}$ between untreated and $15 \mathrm{~min} ; p=0.911$ between untreated and $30 \mathrm{~min}$; one-way ANOVA followed by Tukey's post-test; Fig. 1 E, H). Measurement of the surface mycmGluR1 also showed recovery of the surface fluorescence at the untreated level, 30 min after R,S-DHPG-mediated internalization of the receptor (untreated: $1 \pm 0.05 ; 5$ min: $0.61 \pm 0.05 ; 15$ min: $0.72 \pm 0.06$; 30 min: $0.9 \pm 0.05 ; p=7.427 \times 10^{-7}$ between untreated and $5 \mathrm{~min} ; p=0.00104$ between untreated and $15 \mathrm{~min}$; $p=0.318$ between untreated and $30 \mathrm{~min}$; one-way ANOVA followed by Tukey's post-test; Fig. 1I). It has been reported earlier that myc-mGluR1 normally recycles back to the cell surface at $2.5 \mathrm{~h}$ subsequent to the R,S-DHPG-mediated internalization (Pandey et al., 2014). Thus, these results suggest that in presence of dominant-negative SNX1 myc-mGluR1 undergoes faster recycling as compared with in control cells.

\section{Knockdown of SNX1 results in the faster recycling of mGluR1}

Our earlier experiments suggested that overexpression of dominant-negative SNX1 altered the trafficking of mGluR1. We further confirmed the role of SNX1 in the trafficking of mGluR1 by acute knockdown of endogenous SNX1 in primary hippocampal neurons. Primary hippocampal neurons were cotransfected with myc-mGluR1 cDNA and siRNA against endogenous SNX1 (si-SNX1; ON-TARGET plus) or scrambled siRNA (si-control) at 8-9 DIV. Experiments were performed when the cells were at 12-13 DIV according to the method described in Materials and Methods. The si-SNX1 efficiently knocked down the endogenous SNX1, whereas the si-control did not show any significant knockdown (control: $1 \pm 0.1$; si-SNX1: $0.55 \pm 0.16$; si-control: $1.06 \pm$ $0.1 ; p=0.024$ between control and si-SNX1; $p=0.706$ between control and si-control; one-way ANOVA followed by Tukey's post-test; Fig. 2A,B). Acute knockdown of endogenous SNX1 did 


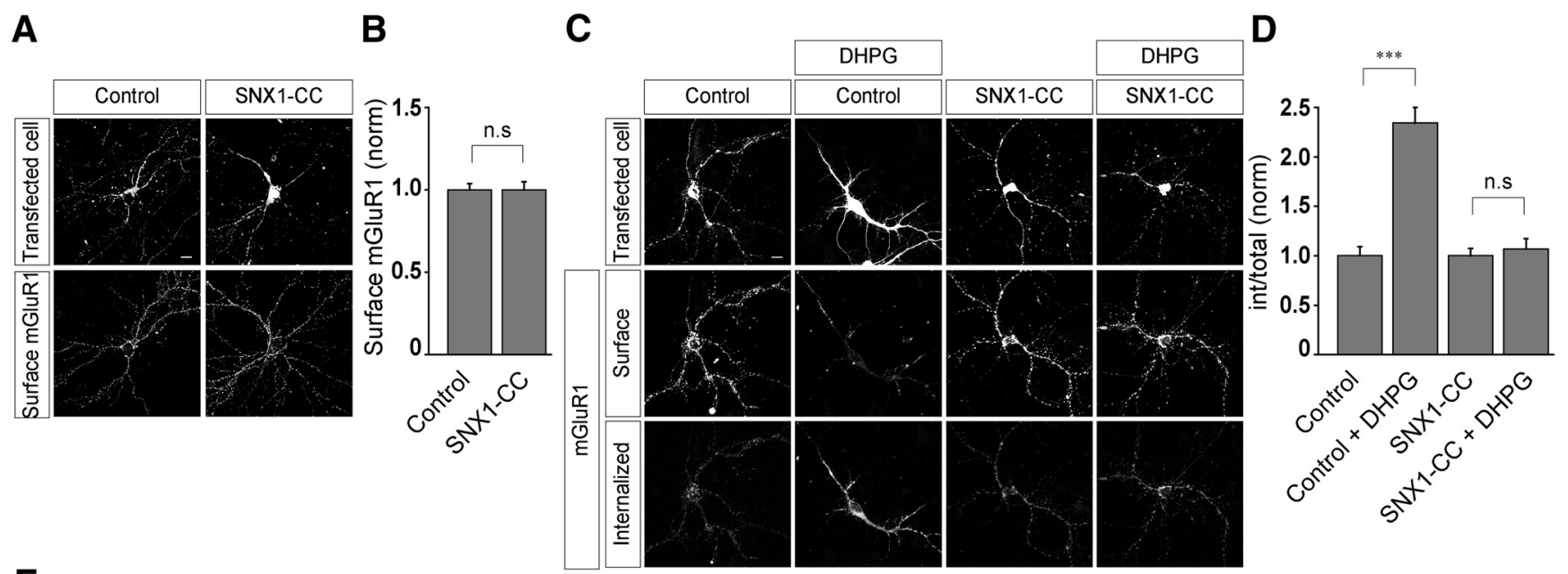

E

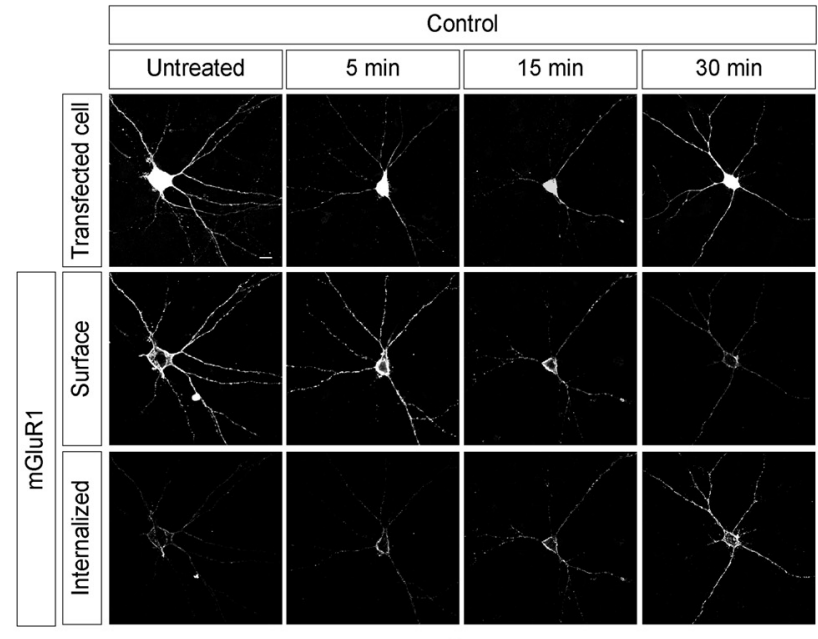

F

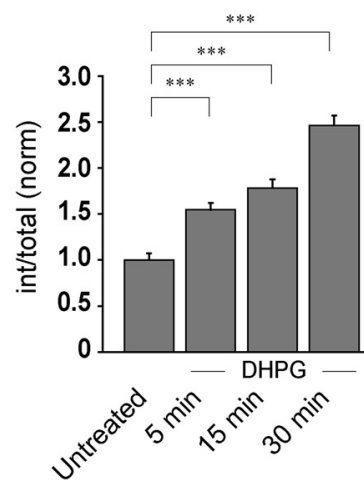

G

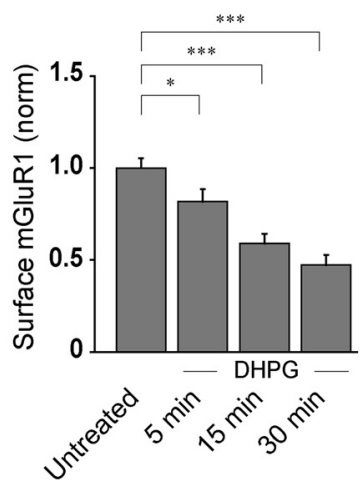

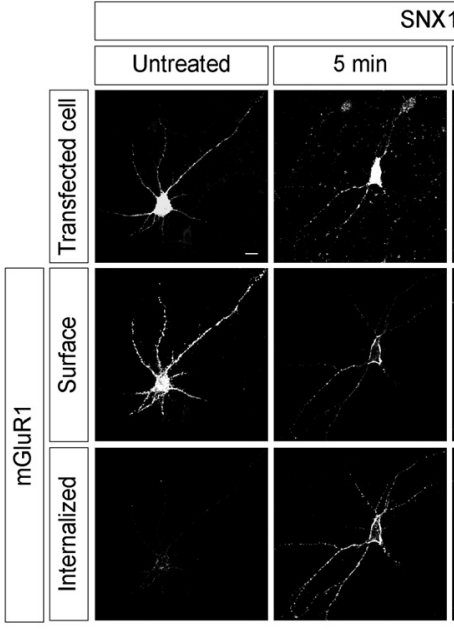

H

SNX1-CC

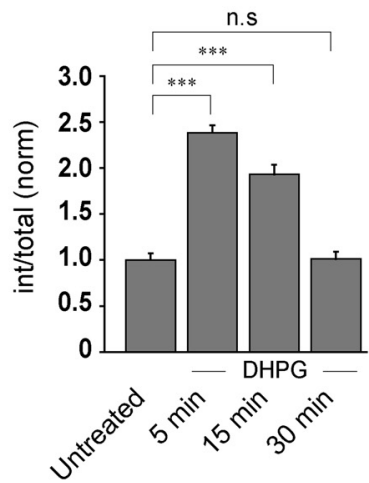

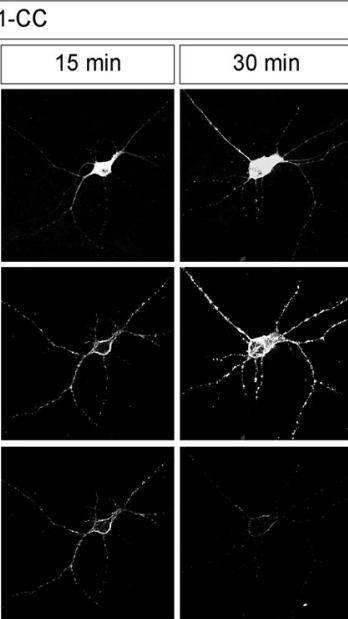

I

SNX1-CC
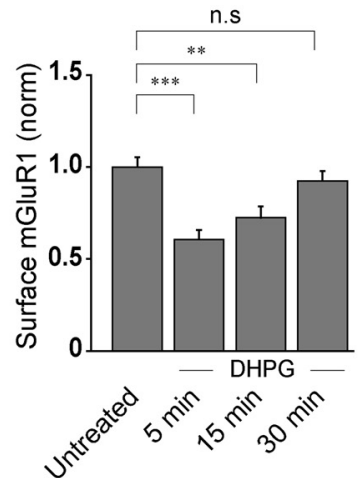

Figure 1. Overexpression of dominant-negative SNX1 (SNX1-CC) results in the faster recycling of mGluR1. A, Representative images show that overexpression of SNX1-CC domain had no effect on the surface expression of myc-mGluR1. B, Quantitation of the effect of SNX1-CC overexpression on the surface expression of myc-mGluR1. C, Overexpression of SNX1-CC domain affected the ligand-mediated trafficking of myc-mGluR1 as shown in representative images. D, Quantitation also shows that SNX1-CC overexpression led to the altered trafficking of myc-mGluR1. $\boldsymbol{E}$, Representative images showing the kinetics of ligand-induced trafficking of myc-mGluR1 in control and SNX1-CC overexpressed cells. $\boldsymbol{F}, \mathbf{G}$, In control cells, upon application of $100 \mu \mathrm{m}$ R,S-DHPG internalization of myc-mGluR1 progressively increased till $30 \mathrm{~min}$ as shown by the quantitation of the endocytosis $(\boldsymbol{F})$ as well as measurement of the surface myc-mGluR1 (G). $\boldsymbol{H}, \boldsymbol{I}, 0 \mathrm{n}$ the other hand, in cells overexpressing SNX1-CC domain, the receptor showed maximum endocytosis at 5 min after $100 \mu \mathrm{MR}, \mathrm{S}$-DHPG application and recycled back to the cell surface at 30 min, as shown by the quantitation of the endocytosis $(\boldsymbol{H})$ and surface localized myc-mGluR1 $(\boldsymbol{I})$. Results are presented as mean \pm SEM collected from three independent experiments. Scale bar, $10 \mu \mathrm{m} .{ }^{* * *} p<0.001$, ${ }^{* *} p<0.01$, ${ }^{*} p<0.05 ;$ n.S., $p>0.05$.

not affect the surface expression of myc-mGluR1 in primary hippocampal neurons (control: $1 \pm 0.05$; si-SNX1: $0.9 \pm 0.06$; sicontrol: $1 \pm 0.08 ; p=0.217$ between control and si-SNX1; $p=$ 0.755 between control and si-control; one-way ANOVA followed by Tukey's post-test; Fig. 2C,D). Importantly, knockdown of en- dogenous SNX1 resulted in the rapid recycling of myc-mGluR1 subsequent to the $100 \mu \mathrm{M}$ R,S-DHPG-mediated internalization of the receptor. The receptor internalized normally upon application of $100 \mu \mathrm{M}$ R,S-DHPG and the extent of internalization increased gradually over time till $30 \mathrm{~min}$ in control cells as well as 

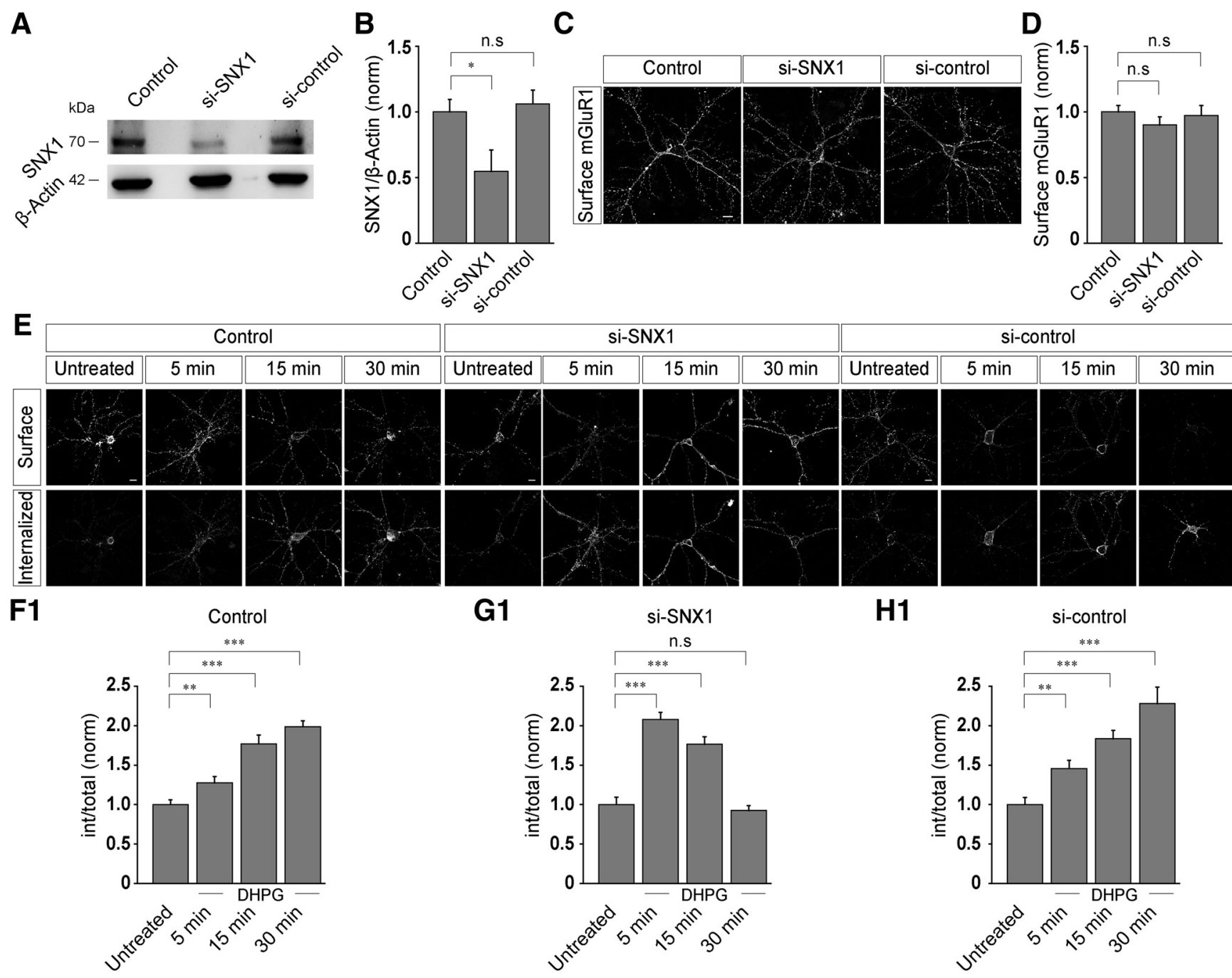

F2

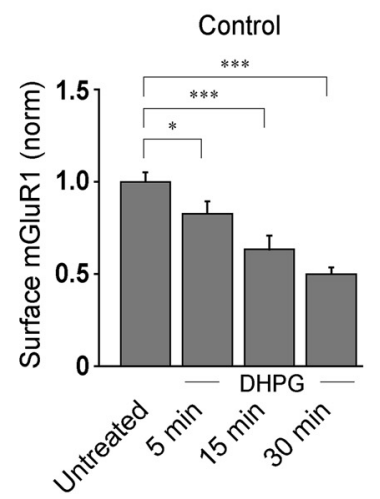

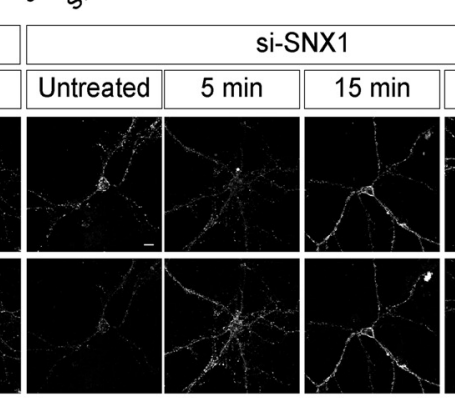

G1

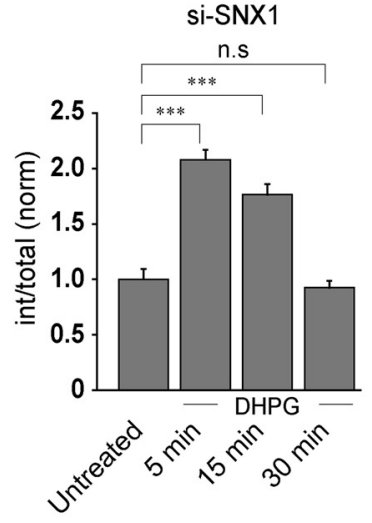

G2

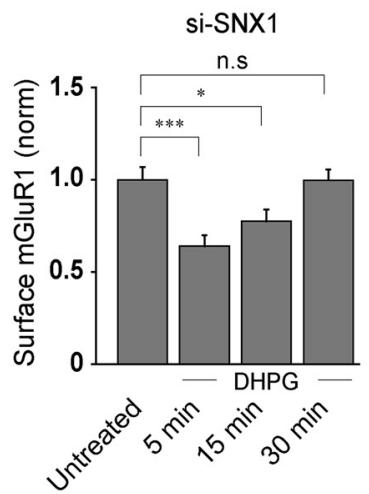

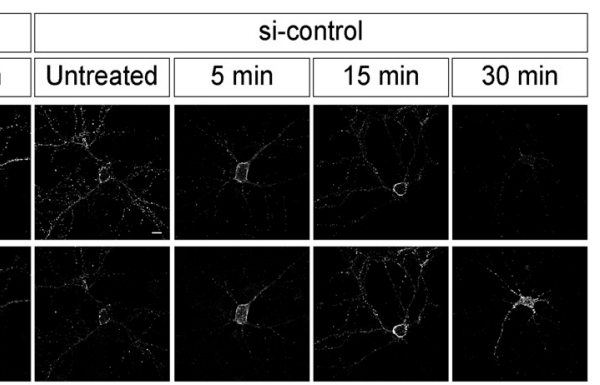

H1

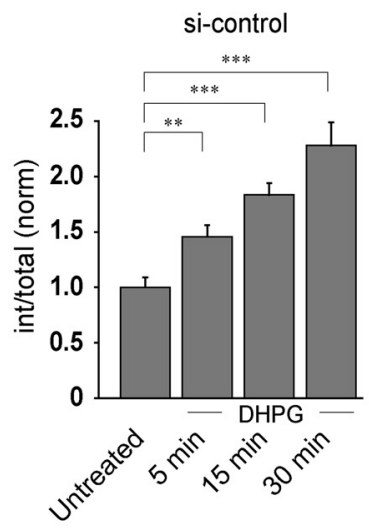

$\mathrm{H} 2$

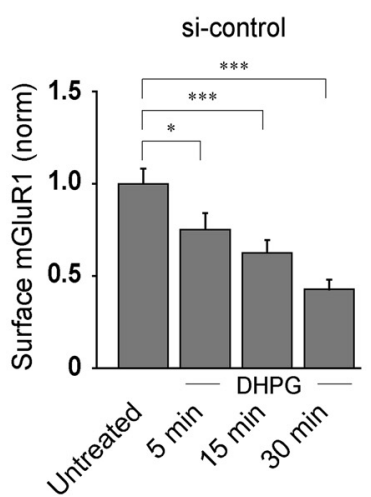

Figure 2. Knockdown of endogenous SNX1 results in the faster recycling of mGluR1. $\boldsymbol{A}, \boldsymbol{B}$, Western blot analyses $(\boldsymbol{A})$ and quantitation of the Western blots $(\boldsymbol{B})$, confirming that the endogenous SNX1 was efficiently knocked down by si-SNX1 in primary neurons. $C$, Representative images show that acute knockdown of endogenous SNX1 had no effect on the surface expression of myc-mGluR1. D, Quantitation of the effect of SNX1 knockdown on the surface expression of myc-mGluR1. $\boldsymbol{E}$, Representative images showing that knockdown of endogenous SNX1 resulted in the recycling of myc-mGluR1 within $30 \mathrm{~min}$ after $100 \mu \mathrm{m}$ R,S-DHPG application, whereas in control cells and si-control treated cells the receptor showed progressive increase in the internalization till 30 min post-ligand application. $\boldsymbol{F 1}, \boldsymbol{F 2}$, Quantitation of the endocytosis $(\boldsymbol{F} \mathbf{1})$ and surface myc-mGluR1 $(\boldsymbol{F} 2)$ also suggested that in control cells the receptor showed maximum endocytosis at 30 min post-ligand application. G1, G2, Importantly, acute knockdown of endogenous SNX1 resulted in the recycling of the receptor to the cell surface within 30 min after $100 \mu \mathrm{M}$ R,S-DHPG application as shown by the quantitation of the endocytosis (G1) and measurement of surface localized myc-mGluR1 (G2). H1, H2, Measurement of the endocytosis (H1) and surface myc-mGluR1 (H2) suggested that $100 \mu \mathrm{m}$ R,S-DHPG induced trafficking of myc-mGluR1 in si-control treated cells was similar to the control cells. Results are presented as mean \pm SEM collected from three independent experiments. Scale bar, $10 \mu \mathrm{m} .{ }^{* * *} p<0.001,{ }^{* *} p<0.01,{ }^{*} p<0.05 ;$ n.s., $p>0.05$.

in si-control transfected cells, whereas, in si-SNX1 transfected cells the receptor recycled back faster, i.e., in $30 \mathrm{~min}$ after $100 \mu \mathrm{M}$ R,S-DHPG application (control:: untreated: $1 \pm 0.06 ; 5$ min: $1.28 \pm 0.08 ; 15 \min : 1.77 \pm 0.11 ; 30 \min : 1.99 \pm 0.08 ; p=0.006$ between untreated and $5 \mathrm{~min} ; p=1.984 \times 10^{-9}$ between untreated and $15 \mathrm{~min} ; p=5.92 \times 10^{-18}$ between untreated and 30 min; one-way ANOVA followed by Tukey's post-test; si-SNX1:: untreated: $1 \pm 0.09 ; 5$ min: $2.08 \pm 0.09 ; 15$ min: $1.76 \pm 0.09 ; 30$ 
A

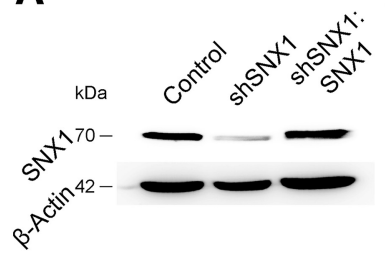

B

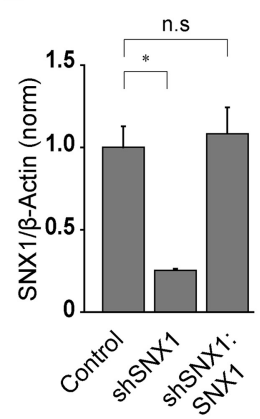

C

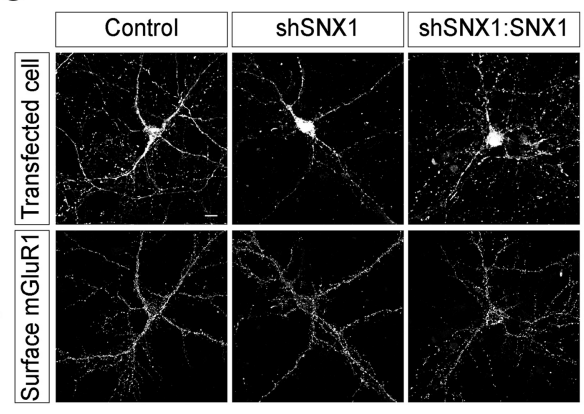

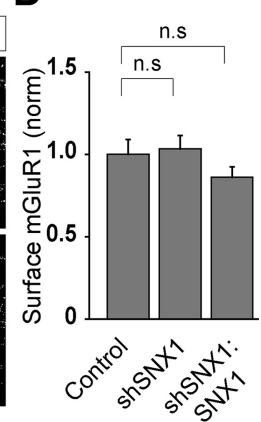

E

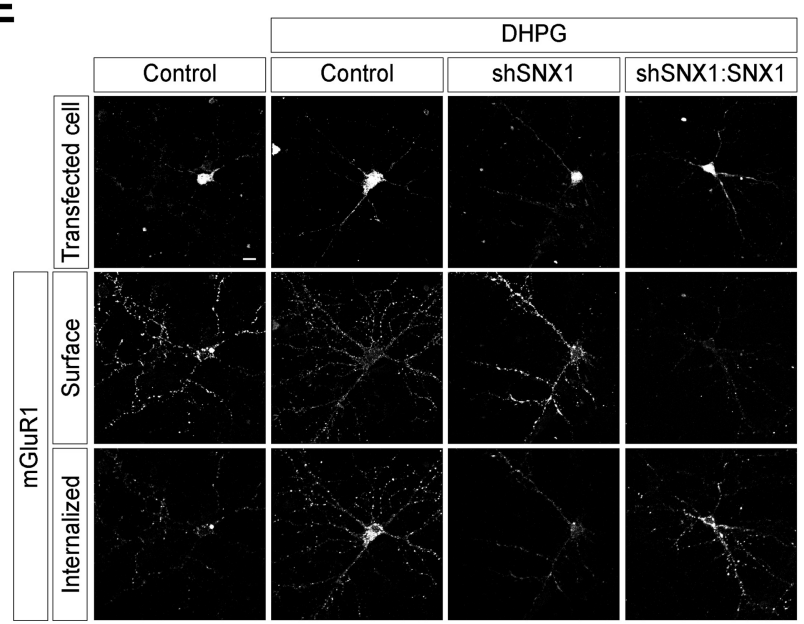

$\mathbf{F}$

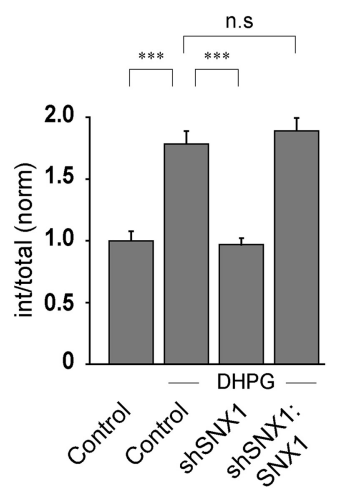

Figure 3. Replacement of endogenous SNX1 with wild-type SNX1 rescues normal trafficking of mGluR1. $\boldsymbol{A}, \boldsymbol{B}$, Western blot $(\boldsymbol{A})$ and quantitation of the Western blots $(\boldsymbol{B})$, showing the efficient knock-down of endogenous SNX1 by shSNX1 and replacement of the endogenous SNX1 with full-length SNX1. C, Representative cells showing that knockdown of endogenous SNX1 with sh SNX1 and expression of the wild-type SNX1 replacement construct had no effect on the surface expression of myc-mGluR1. D, Quantitation of surface myc-mGluR1 following knockdown and replacement of endogenous SNX1.E, Representative examples of surface and internalized myc-mGluR1, 30 min after $100 \mu \mathrm{M} R, S-D H P G$ application in control cells, shSNX1-expressing cells, shSNX1 and wild-type SNX1-expressing cells. $\boldsymbol{F}$, Quantitation suggested that knockdown of endogenous SNX1 resulted in the rapid recycling of myc-mGluR1 and expression of wild-type SNX1 rescued the normal trafficking of the receptor. Results are presented as mean \pm SEM collected from three independent experiments. Scale bar, $10 \mu \mathrm{m} .{ }^{* * *} p<0.001,{ }^{*} p<0.05 ; n$..,$p>0.05$.

min: $0.92 \pm 0.06 ; p=4.015 \times 10^{-12}$ between untreated and 5 $\min ; p=2.228 \times 10^{-7}$ between untreated and $15 \min ; p=0.49$ between untreated and $30 \mathrm{~min}$; one-way ANOVA followed by Tukey's post-test; si-control:: untreated: $1 \pm 0.09 ; 5 \mathrm{~min}: 1.46 \pm$ $0.1 ; 15$ min: $1.83 \pm 0.11 ; 30 \mathrm{~min}: 2.28 \pm 0.21 ; p=0.002$ between untreated and $5 \mathrm{~min} ; p=1.631 \times 10^{-7}$ between untreated and 15 $\min ; p=9.28 \times 10^{-7}$ between untreated and $30 \mathrm{~min}$; one-way ANOVA followed by Tukey's post-test; Fig. 2 E, F1, G1,H1). Measurement of the surface receptors also showed gradual decrease of the receptors from the cell surface on application of $100 \mu \mathrm{M}$ R,SDHPG till $30 \mathrm{~min}$ in both control cells and si-control transfected cells, whereas, in si-SNX1 transfected cells recovery of surface fluorescence was observed at $30 \mathrm{~min}$ post-ligand application (control:: untreated: $1 \pm 0.05 ; 5$ min: $0.83 \pm 0.07 ; 15$ min: $0.63 \pm$ $0.07 ; 30$ min: $0.5 \pm 0.04 ; p=0.042$ between untreated and 5 min; $p=6.634 \times 10^{-5}$ between untreated and $15 \mathrm{~min} ; p=3.07 \times$ $10^{-13}$ between untreated and $30 \mathrm{~min}$; one-way ANOVA followed by Tukey's post-test; si-SNX1:: untreated: $1 \pm 0.07 ; 5 \mathrm{~min}: 0.64 \pm$ 0.06 ; 15 min: $0.78 \pm 0.06 ; 30 \mathrm{~min}: 1 \pm 0.06 ; p=1.977 \times 10^{-4}$ between untreated and $5 \mathrm{~min} ; p=0.021$ between untreated and $15 \mathrm{~min} ; p=0.979$ between untreated and $30 \mathrm{~min}$; one-way ANOVA followed by Tukey's post-test; si-control:: untreated: $1 \pm 0.08 ; 5 \mathrm{~min}: 0.75 \pm 0.09 ; 15 \mathrm{~min}: 0.63 \pm 0.07 ; 30 \mathrm{~min}: 0.43 \pm$ $0.05 ; p=0.046$ between untreated and $5 \mathrm{~min} ; p=9.864 \times 10^{-4}$ between untreated and $15 \mathrm{~min} ; p=1.107 \times 10^{-7}$ between un- treated and $30 \mathrm{~min}$; one-way ANOVA followed by Tukey's posttest; Fig. 2E,F2,G2,H2). These results suggest that SNX1 plays a critical role in the ligand-mediated trafficking of group I mGluRs.

\section{Role of SNX1 domains in the trafficking of mGluR1}

To study the role of various domains and regions of SNX1 in the trafficking of mGluR1, we used molecular replacement strategy that allows simultaneous shRNA-mediated acute knockdown of endogenous SNX1 and expression of mutant forms of recombinant SNX1 in primary hippocampal neurons. There are two important advantages to this approach. First, possibility of compensatory adaptations during synaptogenesis and synapse maturation due to the absence of the protein of interest are minimal. Second, the function of the protein of interest can be studied without having a dominant effect as required by a standard overexpression approach. We initially tested the consequences of acutely knocking down the endogenous SNX1 using a shRNA ( shSNX1) on the ligand-mediated trafficking of mGluR1. This shSNX1 construct was highly effective, as evidenced by the efficient knockdown of endogenous SNX1 measured through Western blot 3-4 d after transfection (control: $1 \pm 0.13$; shSNX1: $0.25 \pm 0.01 ;$ shSNX1:SNX1: $1.08 \pm 0.16 ; p=0.029$ between control and shSNX1; $p=0.723$ between control and shSNX1: SNX1; one-way ANOVA followed by Tukey's post-test; Fig. $3 A, B)$. Consistent with the effect that we observed after knocking 
A

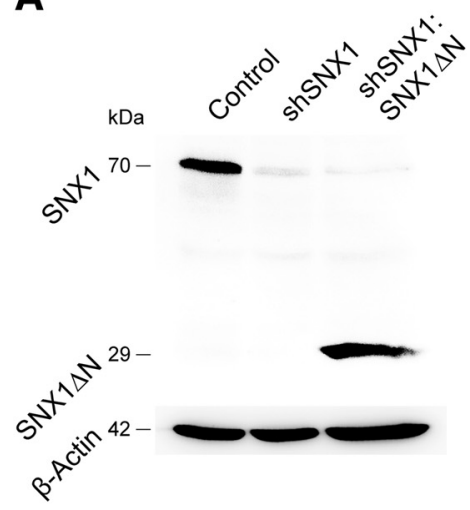

B

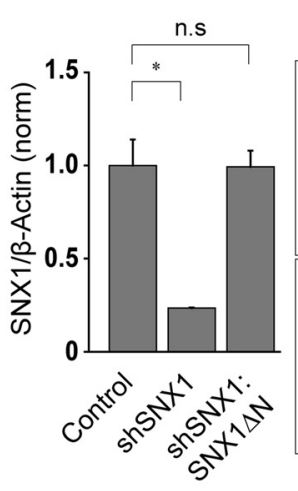

C

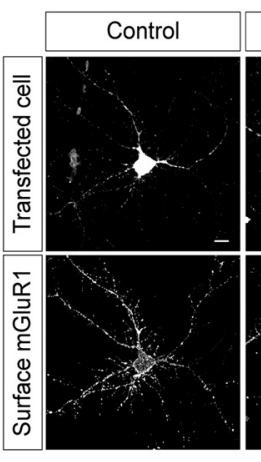

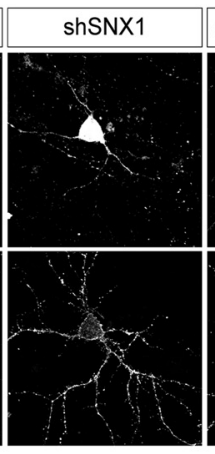
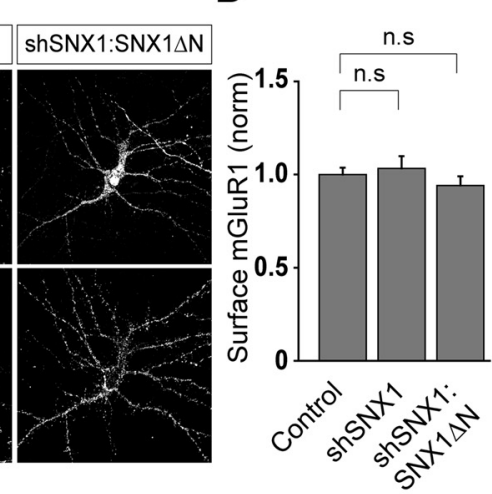

$\mathbf{E}$

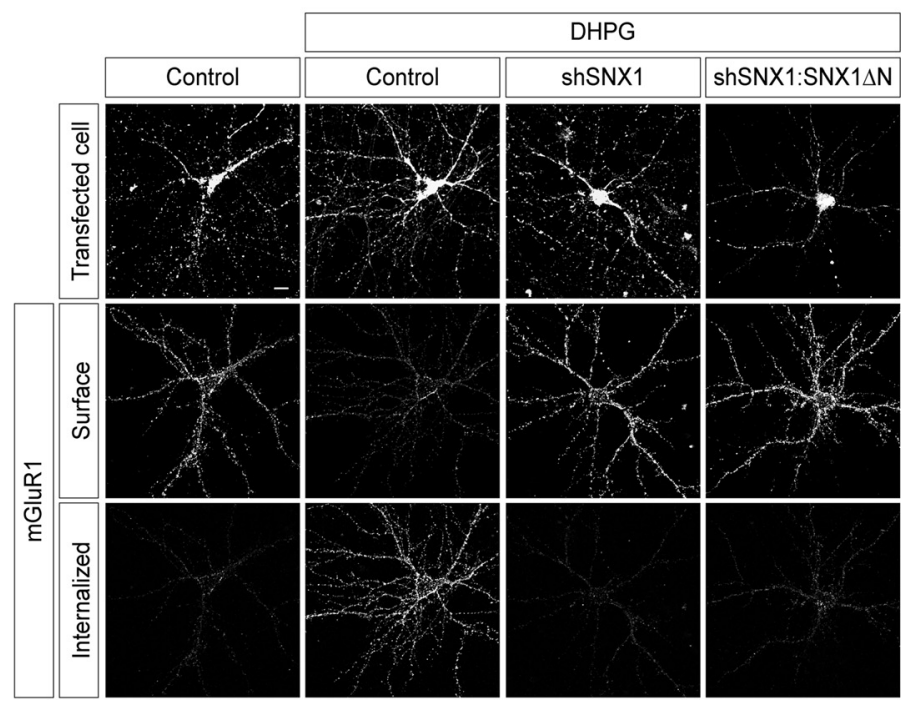

$\mathbf{F}$

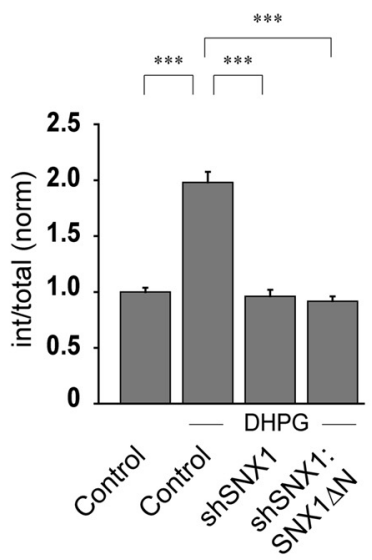

Figure 4. N-terminal domain of SNX1 is required for the normal trafficking of mGluR1. $A, B$, Western blot $(\boldsymbol{A})$ and quantitation of the Western blots $(\boldsymbol{B})$, showing the effective knockdown of endogenous SNX1 by shSNX1 and expression of the SNX1 $\Delta N$ replacement construct. $\boldsymbol{C}, \boldsymbol{D}$, Representative images $(\boldsymbol{C})$ and quantitation $(\boldsymbol{D})$ showing that expression of shSNX1 and shSNX1:SNX1 $\Delta N$ had no effect on the surface expression of myc-mGluR1. $\boldsymbol{E}$, $\boldsymbol{F}$, Representative cells $(\boldsymbol{E})$ and quantitation $(\boldsymbol{F})$ of $100 \mu \mathrm{m}$ R,S-DHPG-induced trafficking of myc-mGluR1 suggested that, knockdown of endogenous $S N X 1$ led to the rapid recycling of myc-mGluR1 in 30 min post-ligand application, and expression of $S N X 1 \Delta N$ replacement construct did not rescue the normal trafficking of the receptor. Results are presented as mean \pm SEM collected from three independent experiments. Scale bar, $10 \mu \mathrm{m} .{ }^{* * *} p<0.001,{ }^{*} p<0.05 ;$ n.s., $p>0.05$.

down of endogenous SNX1 by siSNX1, shRNA-mediated knockdown of SNX1 also did not have any effect on the surface expression of myc-mGluR1. In addition, simultaneous expression of both shSNX1 and HA-tagged wild-type SNX1 also had no effect on the surface expression of myc-mGluR1 (control: $1.0 \pm 0.09$; shSNX1: $1 \pm 0.08$; shSNX1:SNX1: $0.9 \pm 0.06 ; p=0.787$ between control and shSNX1; $p=0.232$ between control and shSNX1: SNX1; one-way ANOVA followed by Tukey's post-test; Fig. $3 C, D)$. We next investigated the effect of the knockdown of endogenous SNX1 on the ligand-mediated trafficking of mycmGluR1. We found that knockdown of endogenous SNX1 resulted in the rapid recycling of myc-mGluR1 (control: $1 \pm 0.08$; control + DHPG: $1.8 \pm 0.1$; shSNX1 + DHPG: $1 \pm 0.05, p=$ $8.939 \times 10^{-8}$ between control and control + DHPG; $p=$ $2.004 \times 10^{-10}$ between control + DHPG and shSNX1 + DHPG; one-way ANOVA followed by Tukey's post-test; Fig. 3E, F). Replacement of the endogenous SNX1 with wild-type SNX1 rescued the normal trafficking of the receptor, as was evident by the presence of the endocytosed receptors at the intracellular compartments at $30 \mathrm{~min}$ after $100 \mu \mathrm{M}$ R,S-DHPG application (shSNX1:SNX1 + DHPG: $1.9 \pm 0.1 ; p=0.494$ between control + DHPG and shSNX1:SNX1 + DHPG; one-way ANOVA fol- lowed by Tukey's post-test; Fig. 3E,F), indicating that the observed phenotype was not due to some nonspecific effects of shSNX1.

SNXs proteins are defined by the presence of a PX domain predicted to bind phosphatidylinositol-3-phosphate and a C-terminal coiled-coil region. To determine the role of SNX1 in group I mGluR trafficking, we first studied the effect of various deletion mutants of SNX1 in mGluR1 trafficking. To examine, whether the N-terminal region of SNX1 plays any role in the trafficking of group I mGluRs, we first replaced the endogenous SNX1 with a form of SNX1 lacking the N-terminal region $(\mathrm{SNX} 1 \Delta \mathrm{N})$. SNX1 $\Delta \mathrm{N}$ was observed to have normal expression levels in primary neurons (control: $1 \pm 0.14$; shSNX1: $0.23 \pm$ 0.003; shSNX1: SNX1 $\Delta \mathrm{N}: 1 \pm 0.09 ; p=0.031$ between control and shSNX1; $p=0.967$ between control and shSNX1: SNX1 $\Delta \mathrm{N}$; one-way ANOVA followed by Tukey's post-test; Fig. 4A,B). Knockdown of endogenous SNX1 and expression of shSNX1: SNX1 $\Delta \mathrm{N}$ did not have any effect on the surface expression of myc-mGluR1 (control: $1.0 \pm 0.04$; shSNX1: $1 \pm 0.07$; shSNX1: SNX1 $\Delta$ N: $0.9 \pm 0.05 ; p=0.663$ between control and shSNX1; $p=0.351$ between control and shSNX1:SNX1 $\Delta \mathrm{N}$; one-way ANOVA followed by Tukey's post-test; Fig. $4 C, D$ ). However, un- 
A

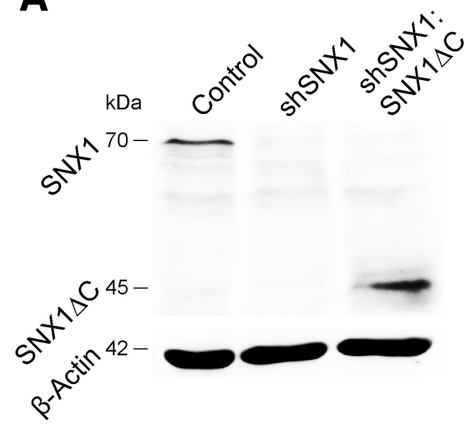

B

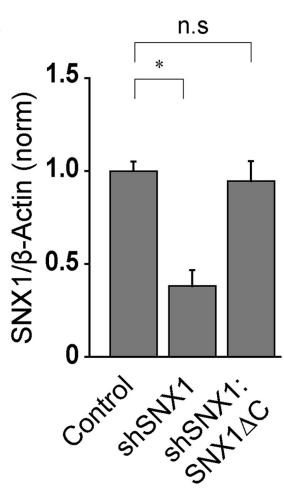

C

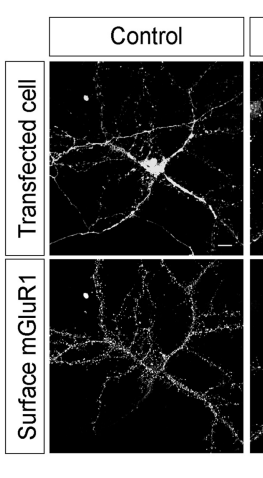

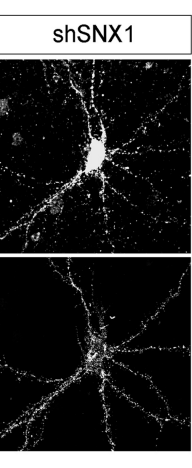

D

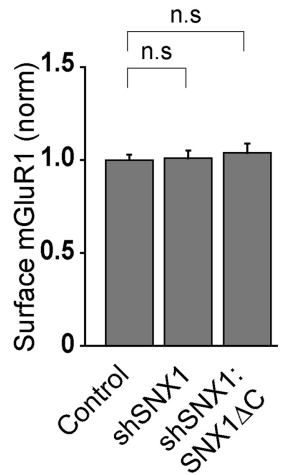

$\mathbf{E}$

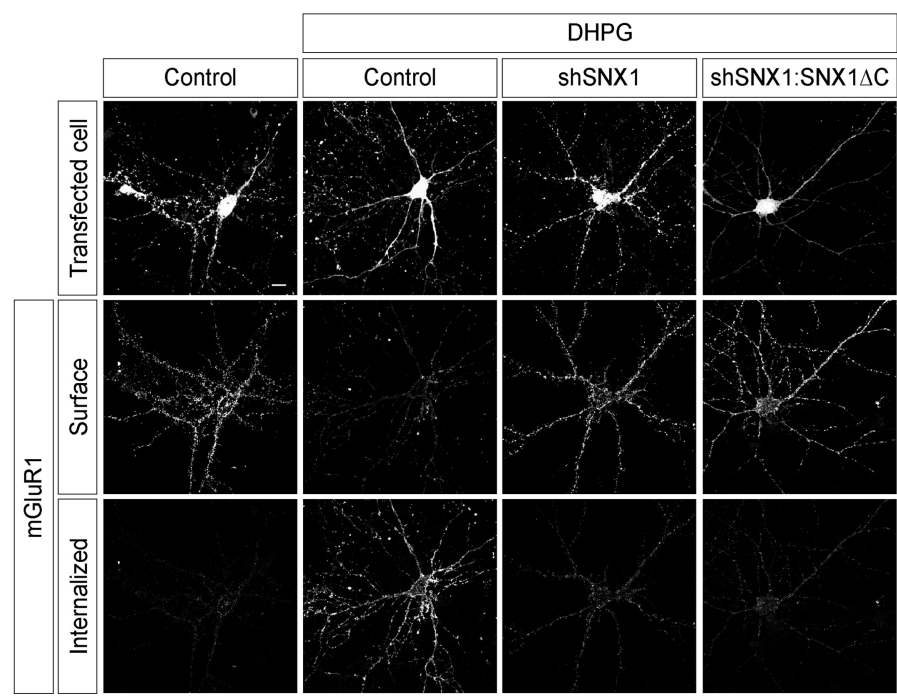

$\mathbf{F}$

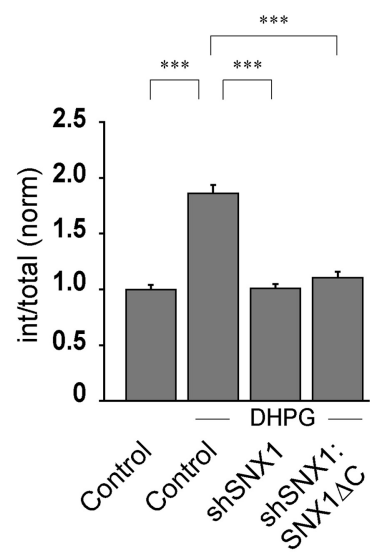

Figure 5. C-terminal domain of SNX1 plays critical role in the normal trafficking of mGluR1. $A, B$, Acute knockdown of endogenous SNX1 and replacement of endogenous SNX1 with SNX1 $\Delta C$, as shown by the Western blot $(\boldsymbol{A})$ and quantitation of the Western blots $(\boldsymbol{B})$. $\boldsymbol{C}, \boldsymbol{D}$, Representative images $(\boldsymbol{C})$ and quantitation $(\boldsymbol{D})$ showing no effect on the surface expression of myc-mGluR1 in shSNX1 and shSNX1:SNX1 $\Delta$ C transfected primary hippocampal neurons. $\boldsymbol{E}, \boldsymbol{F}$, Representative images $(\boldsymbol{E})$ and quantitation $(\boldsymbol{F})$ suggested that knockdown of endogenous SNX1 resulted in the rapid recycling of myc-mGluR1 in 30 min post-ligand application, and replacement of endogenous SNX1 with SNX1 $\Delta$ C failed to rescue the normal trafficking of the receptor. Results are presented as mean \pm SEM collected from three independent experiments. Scale bar, $10 \mu \mathrm{m} .{ }^{* * *} p<0.001,{ }^{*} p<0.05 ;$ n.S., $p>0.05$.

like wild-type SNX1, SNX1 $\Delta \mathrm{N}$ did not rescue the normal recycling of myc-mGluR1 and the receptor still showed rapid recycling in shSNX1:SNX1 $\Delta \mathrm{N}$-expressing cells similar to what was observed in cells where endogenous SNX1 was knocked down (control: $1 \pm 0.04$; control + DHPG: $2 \pm 0.09$; shSNX1 + DHPG: $1 \pm 0.06$; shSNX1:SNX1 $\Delta \mathrm{N}+$ DHPG: $0.9 \pm 0.04 ; p=$ $1.715 \times 10^{-13}$ between control and control + DHPG; $p=$ $2.591 \times 10^{-13}$ between control + DHPG and shSNX1 + DHPG; $p=1.998 \times 10^{-15}$ between control + DHPG and shSNX1: SNX1 $\Delta \mathrm{N}+$ DHPG; one-way ANOVA followed by Tukey's posttest; Fig. $4 E, F)$. Subsequently, we studied the role of the C-terminal region of SNX1 in the trafficking of mGluR1 by replacing the wild-type SNX1 with a form of SNX1 lacking the C-terminal region (SNX1 $\Delta \mathrm{C})$. Similar to other constructs of SNX1, SNX1 $\Delta$ C also appeared to express properly as observed by the Western blot (control: $1 \pm 0.05$; shSNX1: $0.38 \pm 0.09$; shSNX1: SNX1 $\Delta$ C: $0.95 \pm 0.11 ; p=0.025$ between control and shSNX1; $p=0.694$ between control and shSNX1: SNX1 $\Delta \mathrm{C}$; oneway ANOVA followed by Tukey's post-test; Fig. $5 A, B$ ). Expres-

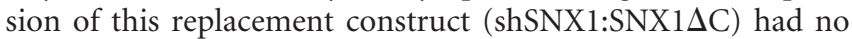
effect on the surface expression of myc-mGluR1 (control: $1.0 \pm$ 0.03; shSNX1: $1 \pm 0.04$; $\operatorname{shSNX1:SNX1\Delta C:~} 1 \pm 0.05 ; p=0.861$ between control and shSNX1; $p=0.505$ between control and shSNX1:SNX1 $\Delta$ C; one-way ANOVA followed by Tukey's posttest; Fig. $5 C, D)$. Similar to the N-terminal deleted SNX1, $\mathrm{SNX} 1 \Delta \mathrm{C}$ also did not rescue the normal recycling of mycmGluR1 and the receptor recycled back in 30 min post-ligandapplication similar to what was observed in SNX1 knockdown cells (control: $1 \pm 0.04$; control + DHPG: $1.9 \pm 0.07$; shSNX1 + DHPG: $1 \pm 0.04$; shSNX1:SNX1 $\Delta \mathrm{C}+$ DHPG: $1.1 \pm 0.05 ; p=$ $1.998 \times 10^{-15}$ between control and control + DHPG; $p=$ $1.998 \times 10^{-15}$ between control + DHPG and shSNX1 + DHPG; $p=1.019 \times 10^{-12}$ between control + DHPG and shSNX1: SNX1 $\Delta \mathrm{C}+$ DHPG; one-way ANOVA followed by Tukey's posttest; Fig. $5 E, F$ ). These results suggest that both $\mathrm{N}$-terminal region as well as the C-terminal region of SNX1 play critical role in the normal trafficking of mGluR1.

\section{C-terminal SH3 domains of SNX1 play critical role in the trafficking of mGluR1}

Our earlier data suggested that the C-terminal region of SNX1 plays important role in the trafficking of mGluR1. SNX1 contains three putative $\mathrm{SH} 3$ domain-binding motifs $(\mathrm{H} 1, \mathrm{H} 2$, and $\mathrm{H} 3)$ at the C-terminal region. Through these domains, SNX1 could po- 
tentially interact with multiple proteins or be involved in the formation of multiprotein complexes via various kinds of interactions. In fact, it has been reported that through these domains SNX1 interacts with Hrs, a protein that has been implicated in both signaling and vesicular trafficking (Chin et al., 2001). To ascertain the role of these domains in the trafficking of group I mGluRs, if any, we made SNX1 replacement constructs viz.,

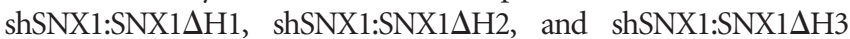
lacking the $\mathrm{H} 1, \mathrm{H} 2$, and $\mathrm{H} 3$ domains, respectively, and studied their effect on the trafficking of mGluR1. Deletion of these domains of SNX1 individually had no effect on the surface expression of mycmGluR1 (control: $1.0 \pm$ 0.04; shSNX1: $0.94 \pm 0.04$; shSNX1: SNX1 $\Delta \mathrm{H} 1: 1 \pm 0.05$; $\operatorname{shSNX1:SNX1\Delta H2:~} 1 \pm 0.06$; shSNX1: $\mathrm{SNX} 1 \Delta \mathrm{H} 3: 1 \pm 0.07 ; p=0.312$ between control and $\operatorname{shSNX} 1 ; p=$ 0.459 between control and shSNX1:SNX1 $\Delta \mathrm{H} 1 ; p=0.877$ between control and shSNX1:SNX1 $\Delta \mathrm{H} 2 ; p=0.685$ between control and shSNX1:SNX1 $\Delta \mathrm{H} 3$; one-way ANOVA followed by Tukey's post-test; Fig. $6 A, B)$. However, unlike wild-type SNX1, $\mathrm{SNX} 1 \Delta \mathrm{H} 2$ and SNX1 $\Delta \mathrm{H} 3$ did not rescue the normal recycling of myc-mGluR1. In shSNX1:SNX1 $\Delta \mathrm{H} 2$ and shSNX1:SNX1 $\Delta \mathrm{H} 3$ transfected cells the receptors recycled back to the cell surface in 30 min post-ligand application, similar to what was observed in shSNX1 transfected cells. On the other hand, SNX1 $\Delta \mathrm{H} 1$ replacement construct rescued the normal trafficking of myc-mGluR1 as observed by the presence of the internalized receptors at $30 \mathrm{~min}$ post-ligand-application, similar to that was observed in control cells (control: $1 \pm$ 0.04; control + DHPG: $2.28 \pm 0.09$; shSNX1 + DHPG: $1 \pm 0.05$; shSNX1:SNX1 $\Delta \mathrm{H} 1+$ DHPG: $2.26 \pm 0.13$;

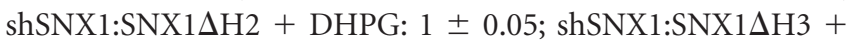
DHPG: $1 \pm 0.08 ; p=3.393 \times 10^{-24}$ between control and control + DHPG; $p=5.818 \times 10^{-22}$ between control + DHPG and shSNX1 + DHPG; $p=0.882$ between control + DHPG and shSNX1:SNX1 $\Delta \mathrm{H} 1+$ DHPG; $p=2.292 \times 10^{-17}$ between control + DHPG and shSNX1:SNX1 $\Delta \mathrm{H} 2+$ DHPG; $p=9.239 \times$ $10^{-17}$ between control + DHPG and shSNX1:SNX1 $\Delta \mathrm{H} 3+$ DHPG; one-way ANOVA followed by Tukey's post-test; Fig. $6 C, D)$. All these replacement constructs showed normal expression levels in Western blot (control: $1 \pm 0.09$; shSNX1: $0.39 \pm$ 0.05; shSNX1:SNX1 $\Delta \mathrm{H} 1: 1.1 \pm 0.06$; $\operatorname{shSNX1:SNX1\Delta H2:~} 1 \pm$ 0.01; shSNX1:SNX1 $\Delta \mathrm{H} 3: 0.96 \pm 0.09 ; p=0.029$ between control and shSNX1; $p=0.462$ between control and shSNX1:SNX1 $\Delta \mathrm{H} 1$; $p=0.934$ between control and shSNX1:SNX1 $\Delta \mathrm{H} 2 ; p=0.789$ between control and shSNX1:SNX1 $\Delta \mathrm{H} 3$; one-way ANOVA followed by Tukey's post-test; Fig. $6 E, F$ ). These results suggest that the $\mathrm{H} 2$ and $\mathrm{H} 3$ domains in the $\mathrm{C}$-terminal region of SNX1 play critical role in the ligand-mediated trafficking of mGluR1. Because an earlier report has suggested that SNX1 interacts with Hrs through its C-terminal region and Hrs has been implicated in vesicular trafficking, we investigated whether binding of SNX1 and Hrs is important for the ligandmediated trafficking of mGluR1. Our data suggested that deletion of $\mathrm{H} 2$ and $\mathrm{H} 3$ domains of SNX1 also disrupted binding of Hrs to SNX1, suggesting that the interaction of SNX1 with Hrs is critical for the trafficking of mGluR1 (Hrs + SNX1: $1 \pm$ 0.06; Hrs + SNX1 $1 \mathrm{H} 1: 1 \pm 0.13$; Hrs + SNX1 $1 \Delta \mathrm{H} 2: 0.43 \pm$ 0.13; Hrs + SNX1 $\Delta \mathrm{H} 3: 0.12 \pm 0.01 ; p=0.935$ between Hrs + SNX1 and Hrs + SNX1 $\Delta \mathrm{H} 1 ; p=0.017$ between Hrs + SNX1 and Hrs + SNX1 $\Delta \mathrm{H} 2 ; p=0.0002$ between Hrs + SNX1 and Hrs + SNX1 $\Delta \mathrm{H} 3$; one-way ANOVA followed by Tukey's posttest; Fig. $6 G, H)$.

\section{Role of Hrs in the ligand-mediated trafficking of mGluR1}

Thus far, our results suggested that interaction of SNX1 with Hrs is critical for the normal ligand-mediated trafficking of mGluR1. To determine whether Hrs plays any role in the trafficking of mGluR1, we knocked down the endogenous Hrs in primary hippocampal neurons. Briefly, cells were cotransfected with mycmGluR1 cDNA and siRNA against endogenous Hrs (si-Hrs; ON-TARGET plus) or scrambled siRNA (si-control) at 8-9 DIV. Subsequently, experiments were conducted when the cells were at 12-13 DIV. The si-Hrs efficiently knocked down the endogenous Hrs in primary neurons (control: $1 \pm 0.03$; si-Hrs: $0.42 \pm 0.07$; si-control: $1.08 \pm 0.15 ; p=0.016$ between control and si-Hrs; $p=0.644$ between control and si-control; one-way ANOVA followed by Tukey's post-test; Fig. $7 A, B$ ). The acute knockdown of Hrs did not have any effect on the surface expression of mycmGluR1 (control: $1 \pm 0.04$; si-Hrs: $1 \pm 0.03$; si-control: $0.98 \pm$ $0.06 ; p=0.715$ between control and si-Hrs; $p=0.791$ between control and si-control; one-way ANOVA followed by Tukey's post-test; Fig. $7 C, D$ ). Importantly, the receptor recycled back faster i.e., in $30 \mathrm{~min}$ after $100 \mu \mathrm{M}$ R,S-DHPG application in si-Hrs transfected cells. On the other hand, in both control cells as well as in si-control transfected cells myc-mGluR1 was observed to be in the internal compartment at $30 \mathrm{~min}$ post-ligand-application (control:: untreated: $1 \pm 0.05 ; 5 \mathrm{~min}: 1.48 \pm 0.07 ; 15 \mathrm{~min}: 2.04 \pm$ 0.09 ; 30 min: $2.5 \pm 0.08 ; p=2.379 \times 10^{-8}$ between untreated and $5 \mathrm{~min} ; p=8.801 \times 10^{-19}$ between untreated and $15 \mathrm{~min} ; p=$ $2.136 \times 10^{-34}$ between untreated and $30 \mathrm{~min}$; one-way ANOVA followed by Tukey's post-test; si-Hrs:: untreated: $1 \pm 0.04 ; 5 \mathrm{~min}$ : $2.54 \pm 0.06 ; 15 \mathrm{~min}: 1.68 \pm 0.07 ; 30 \mathrm{~min}: 1.07 \pm 0.04 ; p=$ $3.829 \times 10^{-31}$ between untreated and $5 \mathrm{~min} ; p=6.454 \times 10^{-12}$ between untreated and $15 \mathrm{~min} ; p=0.295$ between untreated and $30 \mathrm{~min}$; one-way ANOVA followed by Tukey's post-test; si-control:: untreated: $1 \pm 0.07 ; 5 \mathrm{~min}: 1.61 \pm 0.1 ; 15 \mathrm{~min}: 2.11 \pm 0.11$; 30 min: $2.54 \pm 0.17 ; p=1.313 \times 10^{-6}$ between untreated and 5 $\min ; p=7.717 \times 10^{-13}$ between untreated and $15 \mathrm{~min} ; p=$ $1.487 \times 10^{-12}$ between untreated and $30 \mathrm{~min}$; one-way ANOVA followed by Tukey's post-test; Fig. 7 E, F1, G1,H1). Measurement of the surface receptors also showed gradual decrease of the receptors from the cell surface on application of $100 \mu \mathrm{M}$ R,S-DHPG till $30 \mathrm{~min}$ in both control cells and si-control transfected cells, whereas in si-Hrs transfected cells the surface fluorescence recovered at $30 \mathrm{~min}$ (control:: untreated: $1 \pm 0.04 ; 5 \mathrm{~min}: 0.79 \pm 0.04$; 15 min: $0.61 \pm 0.04 ; 30 \mathrm{~min}: 0.44 \pm 0.03 ; p=1.313 \times 10^{-4}$ between untreated and $5 \mathrm{~min} ; p=8.135 \times 10^{-12}$ between untreated and $15 \mathrm{~min} ; p=6.099 \times 10^{-26}$ between untreated and 30 min; one-way ANOVA followed by Tukey's post-test; si-Hrs:: untreated: $1 \pm 0.03 ; 5$ min: $0.47 \pm 0.03 ; 15$ min: $0.68 \pm 0.03 ; 30$ min: $0.94 \pm 0.03 ; p=5.221 \times 10^{-22}$ between untreated and 5 $\min ; p=3.308 \times 10^{-12}$ between untreated and $15 \mathrm{~min} ; p=0.159$ between untreated and $30 \mathrm{~min}$; one-way ANOVA followed by Tukey's post-test; si-control:: untreated: $1 \pm 0.06 ; 5 \mathrm{~min}: 0.73 \pm$ 0.07; 15 min: $0.56 \pm 0.05 ; 30$ min: $0.4 \pm 0.04 ; p=0.004$ between untreated and $5 \mathrm{~min} ; p=9.456 \times 10^{-7}$ between untreated and 15 $\min ; p=1.094 \times 10^{-12}$ between untreated and $30 \mathrm{~min}$; one-way ANOVA followed by Tukey's post-test; Fig. 7 E, F2, G2,H2). These results suggest that Hrs plays a critical role in the normal trafficking of mGluR1 probably through the interaction with SNX1.

\section{SNX1-mediated recycling of mGluR1 is critical for the resensitization of the receptor}

Group I mGluRs undergo desensitization and rapid internalization on ligand exposure and subsequently, recycle back to the cell surface in $2.5 \mathrm{~h}$ (Dhami and Ferguson, 2006; Pandey et al., 2014; 
A

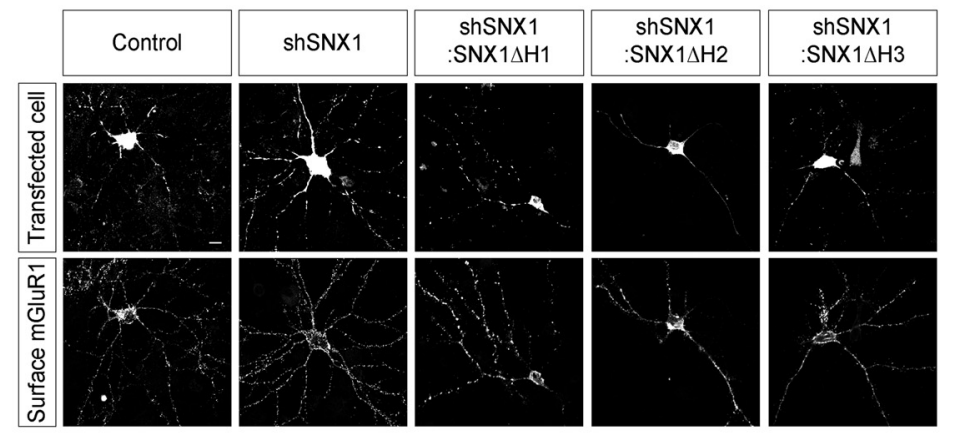

C

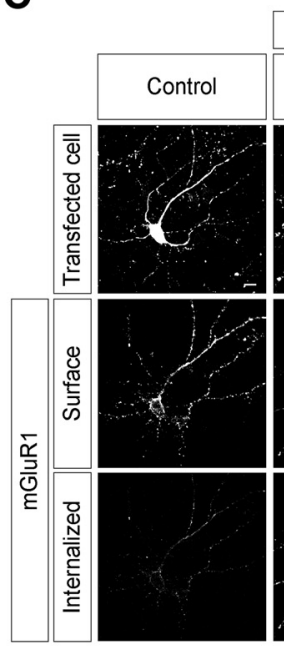

E

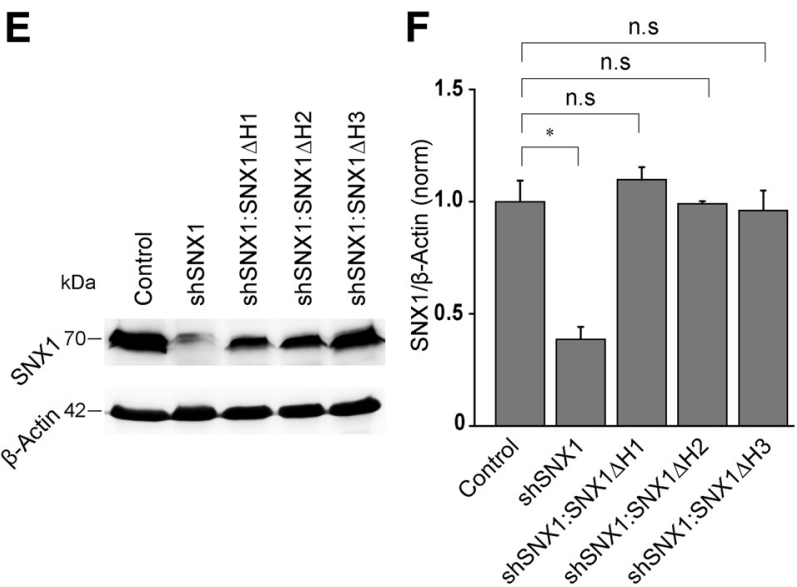

B

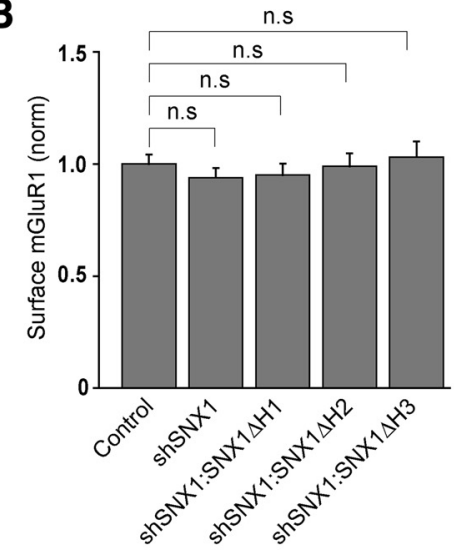

D

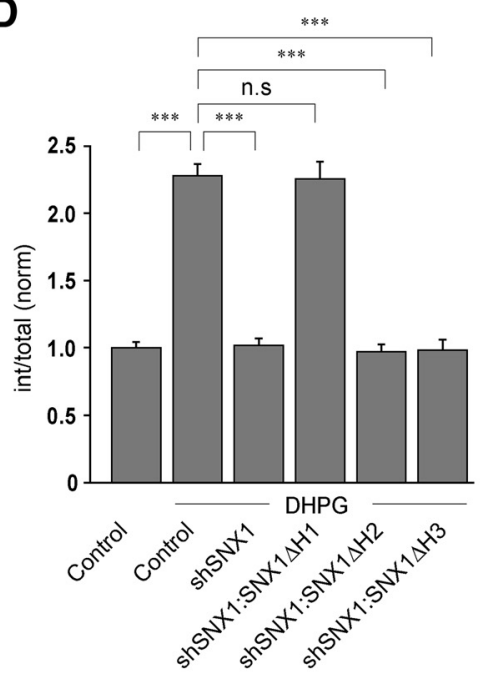

G

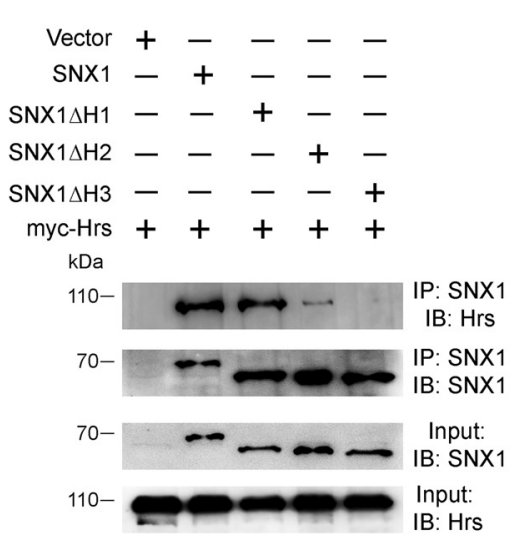

H

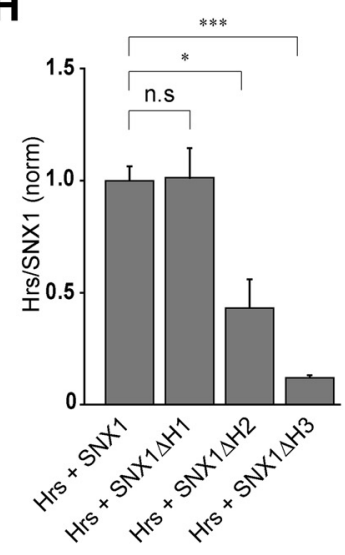

Figure 6. Binding of Hrs to SNX1 is necessary for the normal trafficking of mGluR1. $\boldsymbol{A}, \boldsymbol{B}$, Representative images $(\boldsymbol{A})$ and quantitation $(\boldsymbol{B})$ showing that knockdown of endogenous SNX1 and replacement of endogenous SNX1 with SNX1 $\Delta H 1$, SNX1 $\Delta H 2$, SNX1 $\Delta H 3$ did not have any effect on the surface expression of myc-mGluR1. $C, \boldsymbol{D}$, Representative cells $(\boldsymbol{C})$ and quantitation $(\boldsymbol{D})$ of the R,S-DHPG-mediated trafficking of myc-mGluR1 suggested that, as expected, acute knockdown of endogenous SNX1 led to the rapid recycling of myc-mGluR1 in 30 min post-ligand application. Replacement of endogenous SNX1 with SNX1 $\Delta \mathrm{H} 1$ rescued the normal trafficking of the receptor, but replacement with SNX1 $\Delta \mathrm{H} 2$ or SNX1 $\Delta H 3$ failed to rescue the normal trafficking of the receptor. $\boldsymbol{E}, \boldsymbol{F}$, Western blot $(\boldsymbol{E})$ and quantitation of the Western blots $(\boldsymbol{F})$, showing the knockdown of endogenous SNX1 and expression of shSNX1:SNX1 $\mathrm{H} 1$, shSNX1:SNX1 $\mathrm{H} 2$, shSNX1:SNX1 $\Delta H 3$ constructs. $\mathbf{G}$, Coimmunoprecipitation assays demonstrated that deletion of $\mathrm{H} 2$ or H3 domain of SNX1 disrupted binding of Hrs to SNX1. $\boldsymbol{H}$, Quantitation of the coimmunoprecipitation assays. Results are presented as mean \pm SEM collected from three independent experiments. Scale bar, $10 \mu \mathrm{m} .{ }^{* * *} p<0.001,{ }^{*} p<0.05 ; \mathrm{n}$. .., $p>0.05$.

Mahato et al., 2015). On recycling to the plasma membrane, many receptors are known to resensitize, i.e., functionally recover, such that their responsiveness toward the agonist is restored (Ferguson, 2001; Drake et al., 2006; Sorkin and von Zastrow, 2009). Thus, recycling of the receptor through a proper route is essential for the resensitization of many receptors. To investigate, the effects of SNX1 knockdown on the resensitization of mGluR1, we studied the ability of the recycled receptor to induce the second messenger responses, as well as their ability to initiate the mGluR-mediated AMPAR endocytosis. Group I mGluRs upregulate the phosphorylation of MAPK/ERK1/2 upon activation (Kim et al., 2008; Gladding et al., 2009). Furthermore, 
A

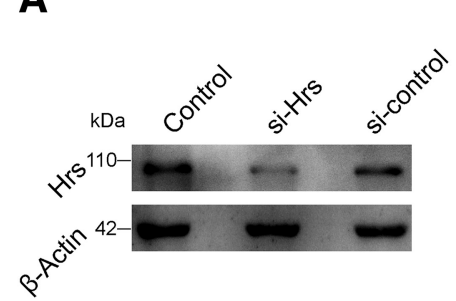

B

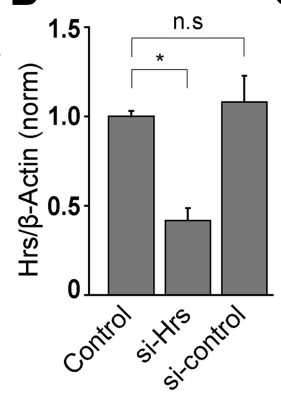

C

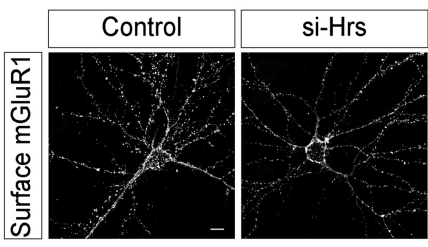

E

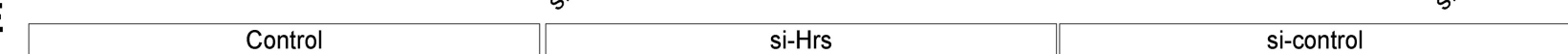

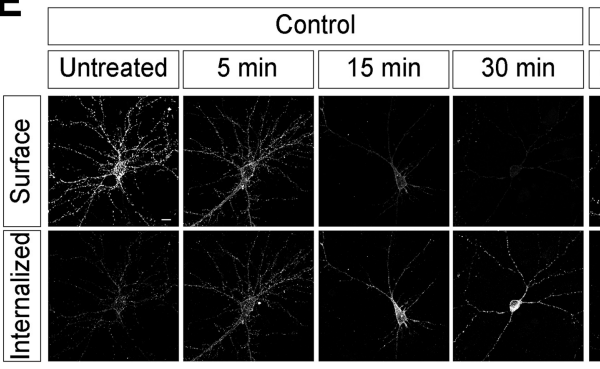

F1

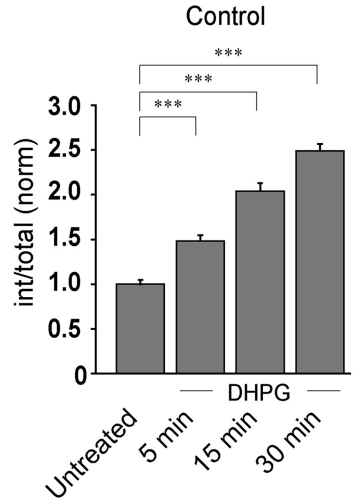

F2

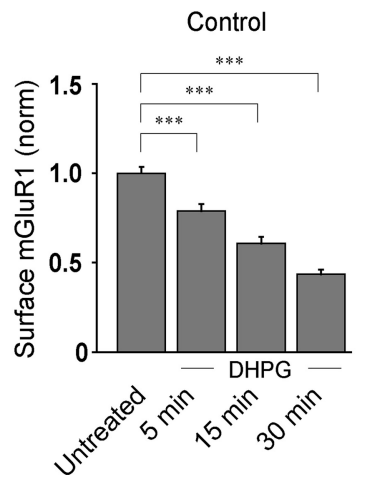

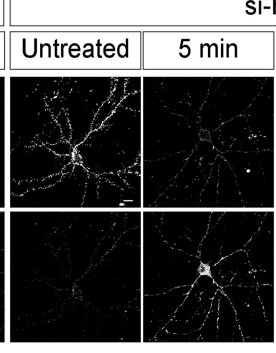

G1

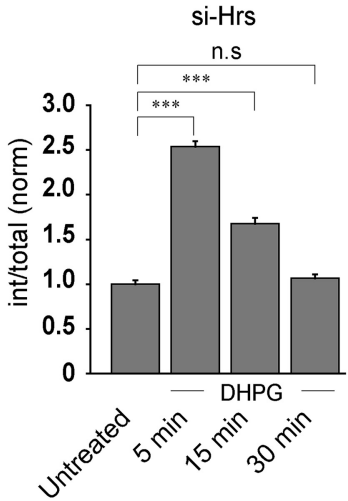

G2

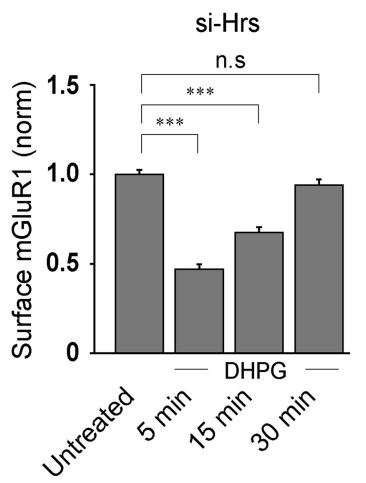

D

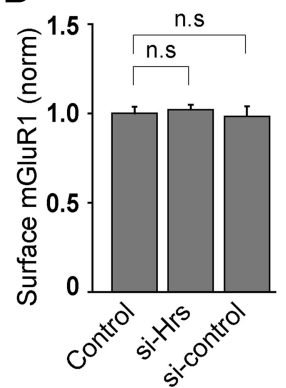

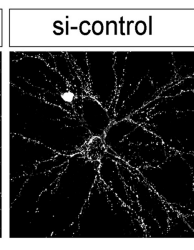

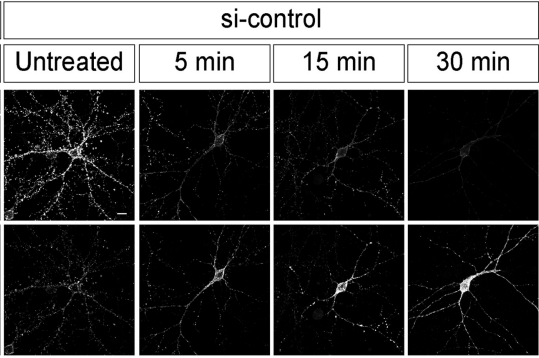

H1

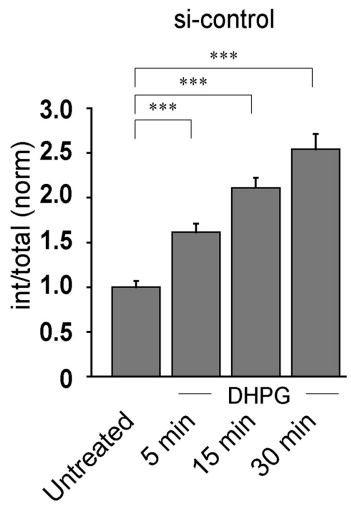

H2

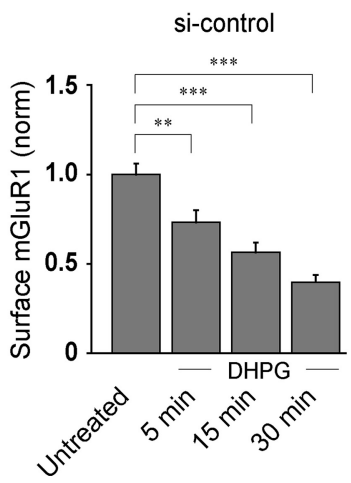

Figure 7. Knockdown of Hrs results in the faster recycling of mGluR1. $\boldsymbol{A}, \boldsymbol{B}$, Western blot analyses $(\boldsymbol{A})$ and quantitation of the Western blots $(\boldsymbol{B})$, showing the efficient knockdown of endogenous Hrs by si-Hrs. $\boldsymbol{C}, \boldsymbol{D}$, Representative images $(\boldsymbol{C})$ and quantitation $(\boldsymbol{D})$ suggested that acute knockdown of endogenous Hrs had no effect on the surface expression of myc-mGluR1. $\boldsymbol{E}$, Representative cells showing that knockdown of endogenous Hrs led to the recycling of myc-mGluR1 within 30 min after $100 \mu \mathrm{M}$ R,S-DHPG application, whereas in control cells and si-control treated cells the receptor showed progressive increase in the internalization till 30 min post-ligand application. $\boldsymbol{F 1}, \boldsymbol{F 2}$, Measurement of the endocytosis $(\boldsymbol{F} 1)$ and surface myc-mGluR1 (F2) also suggested that in control cells myc-mGluR1 showed maximum endocytosis at 30 min after R,S-DHPG application. G1, G2, On the other hand, acute knockdown of endogenous Hrs resulted in the recycling of the receptor within 30 min after $100 \mu \mathrm{M}$ R,S-DHPG application as evident by the quantitation of the endocytosis (G1) and measurement of myc-mGluR1 present at the cell surface (G2). $\boldsymbol{H} \mathbf{1}, \boldsymbol{H 2}$, Quantitation of the endocytosis (H1) and surface myc-mGluR1 $(\boldsymbol{H 2}$ ) suggested that R,S-DHPG-induced trafficking of myc-mGluR1 in si-control treated cells was similar to the control cells. Results are presented as mean \pm SEM collected from three independent experiments. Scale bar, $10 \mu \mathrm{m} .{ }^{* * *} p<0.001,{ }^{* *} p<0.01,{ }^{*} p<0.05 ; \mathrm{n}$. ., $p>0.05$.

AMPARs get endocytosed upon activation of group I mGluRs and mGluR-mediated AMPAR endocytosis is believed to be the cellular correlate for the mGluR-dependent synaptic plasticity (Citri and Malenka, 2008; Gladding et al., 2009; Bhattacharyya, 2016). Cells were first treated with $100 \mu \mathrm{g} / \mathrm{ml}$ cycloheximide for
$5 \mathrm{~h}$ to inhibit the new receptor synthesis and the drug was present throughout the experiment. In control cells, application of 100 $\mu \mathrm{M}$ R,S-DHPG resulted in the increase in the phosphorylation of ERK1/2. When the receptors, that recycled back to the cell surface in $2.5 \mathrm{~h}$ via normal recycling route, were activated by the appli- 
cation of $100 \mu \mathrm{M}$ R,S-DHPG, it again led to the upregulation in the phosphorylation of ERK1/2 (control:: untreated: $1 \pm 0.07$; DHPG: $1.94 \pm 0.1 ; 2.5 \mathrm{~h}$ recycling untreated: $1.03 \pm 0.07 ; 2.5 \mathrm{~h}$ recycling DHPG: $1.84 \pm 0.03 ; p=0.018$ between untreated and DHPG; $p=0.01$ between $2.5 \mathrm{~h}$ recycling untreated and $2.5 \mathrm{~h}$ recycling DHPG; $p=0.803$ between untreated and $2.5 \mathrm{~h}$ recycling untreated; one-way ANOVA followed by Tukey's post-test; Fig. $8 A, B)$. These results suggest that the receptors that came back to the cell surface through normal recycling route were resensitized. In shSNX1 transfected cells, initial application of 100 $\mu \mathrm{M}$ R,S-DHPG also resulted in the rise in the phosphorylation of ERK1/2. Importantly, the receptors that recycled back to the cell surface in $30 \mathrm{~min}$ following rapid recycling route were unable to increase the phosphorylation of ERK1/2, upon activation with $100 \mu \mathrm{M}$ R,S-DHPG (shSNX1:: untreated: $1 \pm 0.01$; DHPG: $1.79 \pm 0.01 ; 30 \mathrm{~min}$ recycling untreated: $1.14 \pm 0.04 ; 30 \mathrm{~min}$ recycling DHPG: $1.24 \pm 0.03 ; p=0.0003$ between untreated and DHPG; $p=0.217$ between 30 min recycling untreated and 30 min recycling DHPG; $p=0.082$ between untreated and $30 \mathrm{~min}$ recycling untreated; one-way ANOVA followed by Tukey's posttest; Fig. 8C,D).

To check for the ability of the recycled mGluRs to induce the AMPAR endocytosis, we used the protocol that results in the mGluR-mediated endocytosis of synaptic AMPARs (Gulia et al., 2017). In control cells, initial application of R,S-DHPG (100 $\mu \mathrm{M}$ for $5 \mathrm{~min}$ ) in the presence of $1 \mu \mathrm{M}$ TTX, $20 \mu \mathrm{M}$ DNQX and $50 \mu \mathrm{M}$ APV, resulted in the endocytosis AMPARs (control:: untreated: $1 \pm$ 0.04; DHPG: $2.02 \pm 0.05 ; p=3.324 \times 10^{-27}$ between untreated and DHPG; one-way ANOVA followed by Tukey's posttest; Fig. $8 E, F)$. The mGluRs that recycled to the cell surface in $2.5 \mathrm{~h}$ through the normal recycling route, also showed the ability to induce the AMPAR endocytosis when they were stimulated with $100 \mu \mathrm{M}$ R,S-DHPG for 5 min (control:: 2.5 h recycling untreated: $1 \pm 0.04 ; 2.5$ h recycling DHPG: $1.97 \pm 0.07 ; p=1.911 \times$ $10^{-17}$ between $2.5 \mathrm{~h}$ recycling untreated and $2.5 \mathrm{~h}$ recycling DHPG; one-way ANOVA followed by Tukey's post-test). We have reported earlier, that the recycling of group I mGluRs is PP2A and PP2B dependent (Pandey et al., 2014; Mahato et al., 2015). When the recycling of the receptors was blocked by $5 \mathrm{~nm}$ Okadaic acid and $1 \mu \mathrm{M}$ FK-506 (PP2A and PP2B inhibitors, respectively), application of $100 \mu \mathrm{M}$ R,S-DHPG did not induce endocytosis of AMPARs (control:: 2.5 h no recycling untreated: $1 \pm 0.04 ; 2.5$ h no recycling DHPG: $1 \pm 0.05 ; p=0.686$ between $2.5 \mathrm{~h}$ no recycling untreated and $2.5 \mathrm{~h}$ no recycling DHPG; oneway ANOVA followed by Tukey's post-test). It has been reported, that in the hippocampal neurons both FK-506 and OA had no effect on the basal transmission, suggesting that both these drugs do not affect the basal trafficking of GluA1-containing receptors (Schnabel et al., 2001). In shSNX1 transfected cells, initial application of $100 \mu \mathrm{M}$ R,S-DHPG for $5 \mathrm{~min}$ led to the endocytosis of AMPARs (shSNX1:: untreated: $1 \pm 0.05$; DHPG: $1.9 \pm 0.05 ; p=$ $2.177 \times 10^{-18}$ between untreated and DHPG; one-way ANOVA followed by Tukey's post-test; Fig. $8 G, H$ ). However, the receptors that recycled to the cell surface in $30 \mathrm{~min}$ via the rapid recycling route, were not able to induce the endocytosis AMPARs, when they were stimulated with $100 \mu \mathrm{M}$ R,S-DHPG for $5 \mathrm{~min}$ (shSNX1:: 30 min recycling untreated: $1 \pm 0.03 ; 30$ min recycling DHPG: $0.93 \pm 0.04 ; p=0.175$ between 30 min recycling untreated and $30 \mathrm{~min}$ recycling DHPG; one-way ANOVA followed by Tukey's post-test). These results suggest that the recycling of mGluR1 through normal recycling route, subsequent to the ligand-dependent internalization, is required for the resensitization of the receptor. The rapid recycling route that mGluR1 takes in absence of SNX1, does not allow the receptor to be resensitized and the receptor recycled to the cell surface as inactive receptor.

\section{Discussion}

The detailed molecular mechanisms underlying the trafficking of group I mGluRs are of great interest because of the critical roles trafficking plays in the regulation of the activity of these receptors as well as their localization at a specific place in the neuron. Inappropriate trafficking of the receptor could lead to improper signaling with pathological consequences. In the present study, we have defined a novel role for SNX1 in the ligand-mediated trafficking of group I mGluRs. Our earlier data suggested that group I mGluRs enter the recycling compartment subsequent to the ligand-dependent internalization and they recycle back to the cell surface at $2.5 \mathrm{~h}$ post-ligand application (Pandey et al., 2014). Like many other GPCRs, the recycling is probably a critical step to "resensitize" these receptors. SNXs are a large group of proteins defined by the presence of PX domain and various reports have suggested that a member of this family, SNX1 could play important role in controlling the trafficking and sorting of some receptors. SNX1 has also been shown to interact in vitro with the cytoplasmic tails of both members of group I mGluR family, viz., mGluR1 and mGluR5, suggesting that SNX1 might play a critical role in the trafficking of group I mGluRs (Heydorn et al., 2004). In light of all the above evidences, we studied the role of SNX1, if any, in the trafficking of group I mGluRs in primary hippocampal neurons. Our data suggest that SNX1 plays critical role in regulating the recycling of mGluR1. Consequently, either upon SNX1 knockdown or overexpression of the dominant-negative SNX1, mGluR1 was re-sorted via the faster recycling route and the receptor recycled back to the cell surface at $30 \mathrm{~min}$ post-ligand application. Subsequently, primarily using a strategy in which mutant forms of SNX1 replace endogenous SNX1 that has been knocked down by shRNA, we found that SNX1 is important for the normal recycling of mGluR1, because of its binding to Hrs. Hrs is a protein that has been implicated in both signaling and vesicular trafficking (Chin et al., 2001). At this point, it is not clear what drives the mGluR1 in the rapid recycling route in absence of SNX1. The existence of a fast recycling route back to the plasma membrane has been documented for many receptors (Grant and Donaldson, 2009; Yudowski et al., 2009). Early studies identified Rab4 as being important for the recycling of receptors through faster recycling route (van der Sluijs et al., 1992; Maxfield and McGraw, 2004). However, the mechanism by which Rab4 mediates the faster recycling of those receptors is not clear. Subsequently, another protein, viz., Rab35 has been implicated as an important regulator of rapid recycling (Kouranti et al., 2006; Sato et al., 2008). It would be interesting to investigate whether in absence of SNX1, Rab4, or Rab35 or both play critical role in resorting the receptor via the faster recycling route.

Both N-terminal region and C-terminal region of SNX1 seems to be important for the normal trafficking of mGluR1. The receptor still took the rapid recycling route when the endogenous SNX1 was replaced with SNX1 lacking the N-terminal region $(\mathrm{SNX} 1 \Delta \mathrm{N})$ and SNX1 lacking the C-terminal region (SNX1 $\Delta \mathrm{C})$. The N-terminal region of SNX1 contains PX domain that interacts with phosphatidylinositol's (PtdIns; Cozier et al., 2002; Cullen, 2008). On the other hand, the C-terminal region of SNX1 is involved in protein-protein interactions (Chin et al., 2001; Zhong et al., 2002; Cullen, 2008). Because our interest was to investigate the mechanisms through which SNX1 along with its downstream binding partners modulate the trafficking of mGluR1, we therefore focused our study to investigate how the C-terminal region 
A

Control
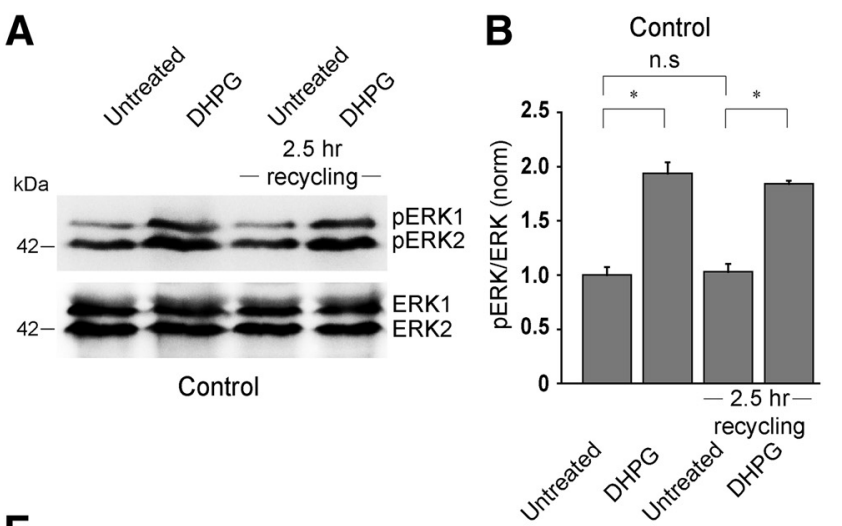

E
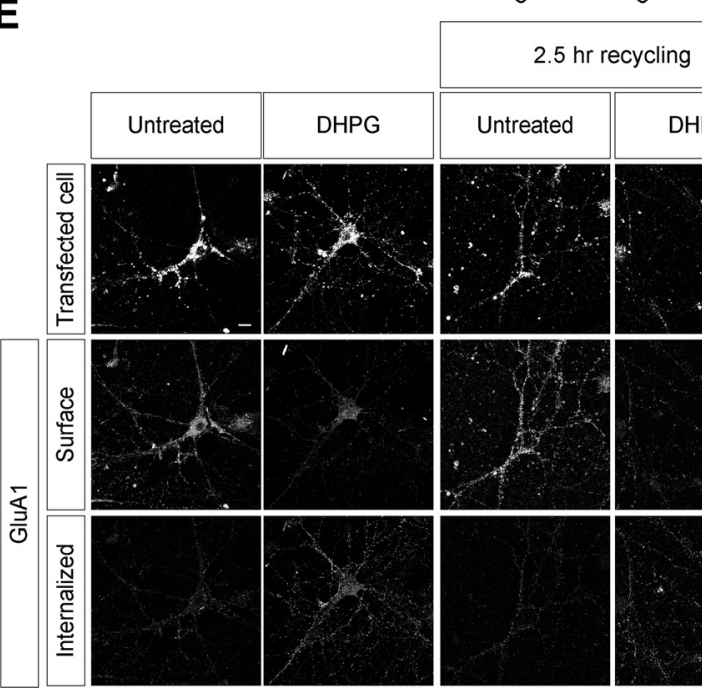

C

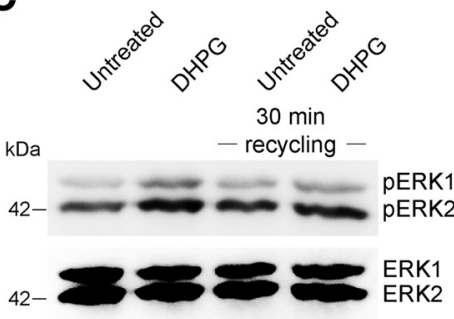

shSNX1
D $\quad$ shSNX1

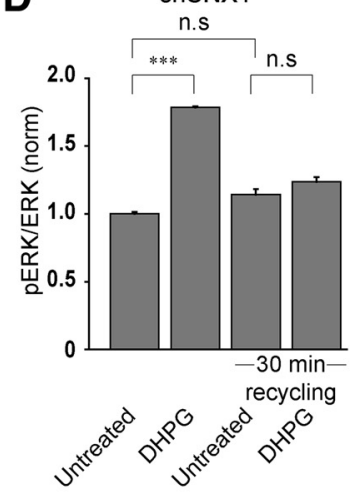

$\mathbf{F}$

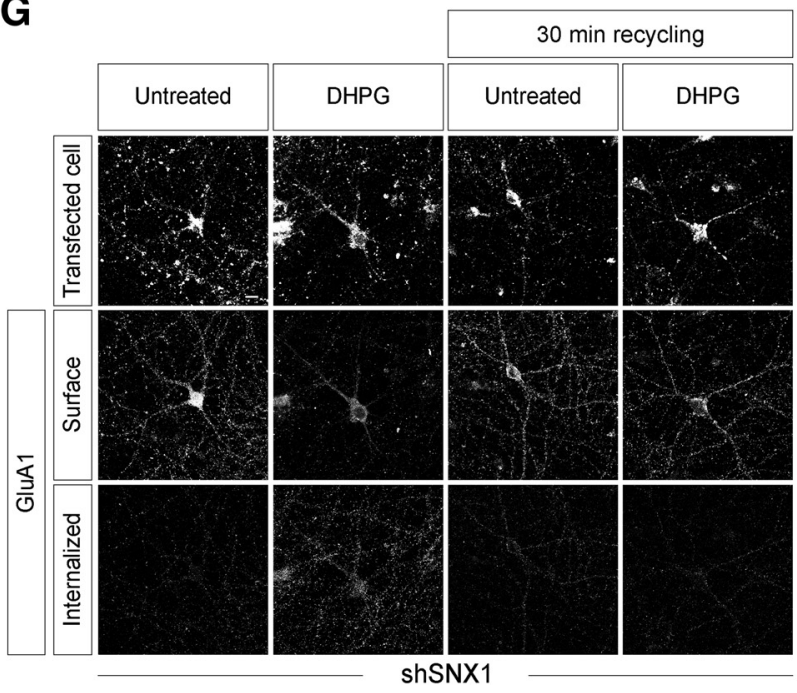

Control

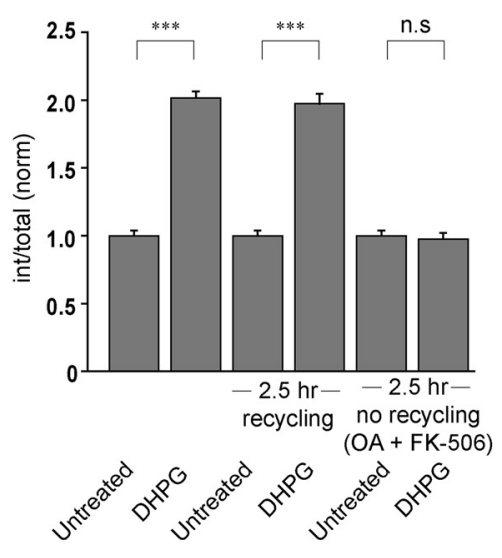

H

shSNX1
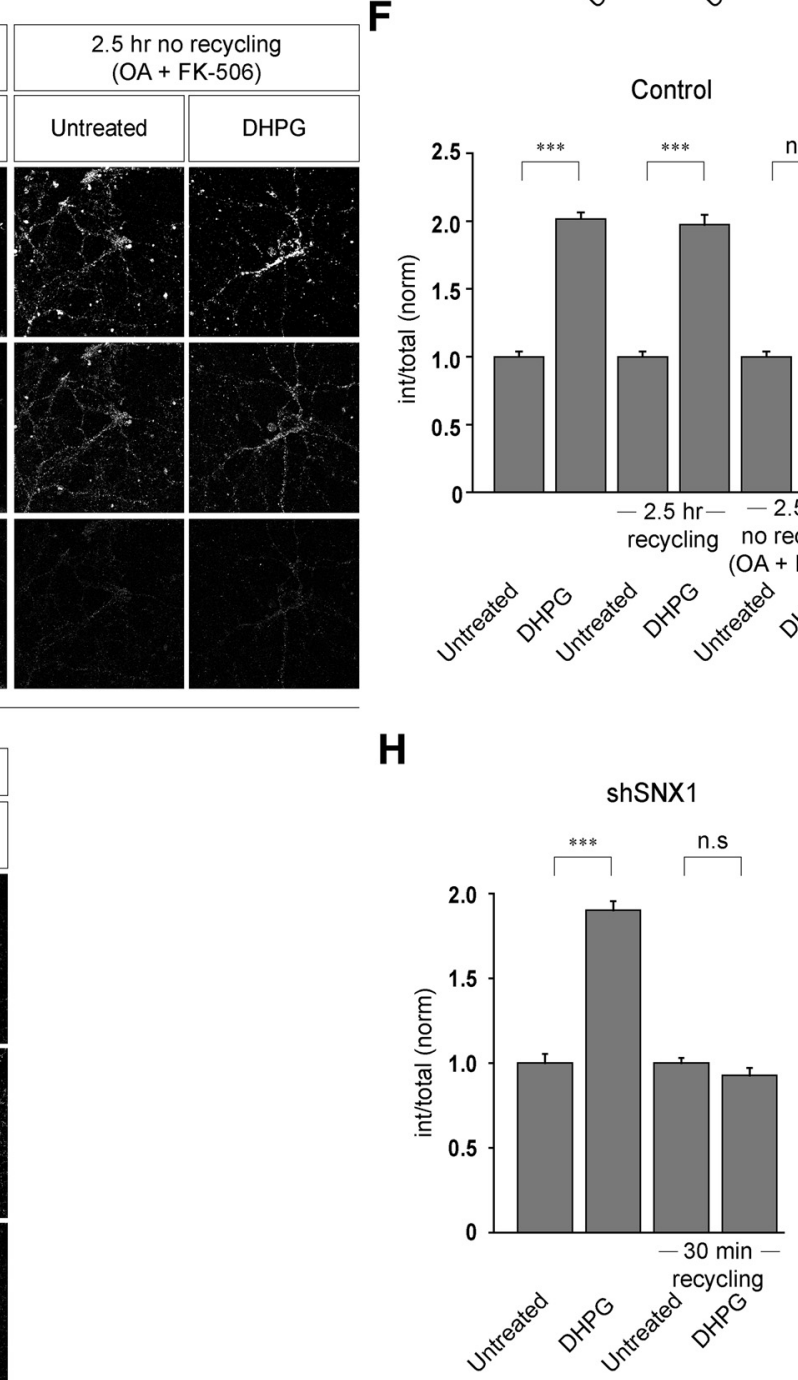

Figure 8. SNX1 regulates the resensitization of mGluR1. $\boldsymbol{A}, \boldsymbol{B}$, Western blot $(\boldsymbol{A})$ and quantitation of the Western blots $(\boldsymbol{B})$ showing that application of $100 \mu \mathrm{M}$ R,S-DHPG for 5 min led to the phosphorylation of MAP kinases. Furthermore, the receptors recycled to the cell surface following normal recycling route in $2.5 \mathrm{~h}$, also showed the ability to induce phosphorylation of MAP kinases on application of $100 \mu \mathrm{M}$ R,S-DHPG for $5 \mathrm{~min}$. C, D, Western blot (C) and quantitation (D) suggested that although in SNX1 knockdown cells, initial application of $100 \mu \mathrm{m}$ R,S-DHPG for 5 min led to the phosphorylation of MAP kinases, but the receptors that recycled back in 30 min post-ligand application, following the rapid recycling route, were unable to induce the phosphorylation of MAP kinases on application of $100 \mu \mathrm{m}$ R,S-DHPG for $5 \mathrm{~min} . \boldsymbol{E}$, $\boldsymbol{F}$, Representative images $(\boldsymbol{E})$ and quantitation of the mGluR-mediated AMPAR endocytosis $(\boldsymbol{F})$ suggested that in control cells, the receptors that recycled back to the cell surface following normal recycling route in $2.5 \mathrm{~h}$, were able to induce the endocytosis of GluA1-containing receptors when they were stimulated with $100 \mu \mathrm{M} R, S-\mathrm{DHPG}$ for $5 \mathrm{~min}$. On the other hand, application of $100 \mu \mathrm{m}$ R,S-DHPG did not cause endocytosis of GluA1-containing receptors when the mGluR recycling was inhibited with okadaic acid and FK-506. $\mathbf{G}, \boldsymbol{H}$, Representative images $(\boldsymbol{G})$ and quantitation of the mGluR-mediated AMPAR endocytosis $(\boldsymbol{H})$ showed that in shSNX1 transfected cells, although initial application of $100 \mu \mathrm{M}$ R,S-DHPG for 5 min led to the endocytosis of GluA1-containing receptors, but the receptors that recycled back to the cell surface through rapid recycling route in 30 min post-ligand application, did not have the ability to induce the internalization of GluA1-containing receptors. Results are presented as mean \pm SEM collected from three independent experiments. Scale bar, $10 \mu \mathrm{m} .{ }^{* * *} p<0.001,{ }^{*} p<0.05 ;$ n.S., $p>0.05$. 
of SNX1 plays critical role in the trafficking of mGluR1. The C-terminal region of SNX1 contains three putative SH3 domainbinding motifs ( $\mathrm{H} 1, \mathrm{H} 2$, and $\mathrm{H} 3$ ). Through these domains SNX1 might interact with multiple proteins and in fact, it has been reported that through these domains SNX1 interacts with Hrs, a protein that has been implicated in both signaling and vesicular trafficking (Chin et al., 2001). We therefore studied the role of these domains in the trafficking of mGluR1. Interestingly, we found that deletion of $\mathrm{H} 1$ domain of SNX1 had no effect on the trafficking of the receptor, whereas, deletion of $\mathrm{H} 2$ or $\mathrm{H} 3$ domain resulted in the rapid recycling of the receptor. Furthermore, our data suggest that both $\mathrm{H} 2$ and $\mathrm{H} 3$ domains of SNX1 are necessary for the interaction of SNX1 with Hrs. We therefore hypothesize at this point that interaction of Hrs to SNX1 is critical for the normal trafficking of mGluR1. Our hypothesis was strengthened by the observation that acute knockdown of endogenous Hrs also resulted in the rapid recycling of the receptor. Importantly, we show here that mGluRs that came back to the cell surface via faster recycling route, in absence of SNX1, were inactive. In other words, those receptors were unable to induce the second messenger responses as observed by their inability to upregulate the phosphorylation of MAP kinases. Moreover, they were also unable to induce the AMPAR endocytosis, which is a prerequisite for the mGluR-mediated synaptic plasticity. On the other hand, when the receptors were allowed to recycle back to the cell surface via the slower recycling route in wild-type cells, the recycled receptors were able to upregulate the phosphorylation of MAP kinases and induction of the AMPAR endocytosis. These results indicate that SNX1-mediated recycling of these receptors via the slower recycling route is critical for the resensitization of these receptors.

In conclusion, we have shown here that group I mGluR trafficking is mediated by SNX1 through the interaction with Hrs in primary hippocampal neurons. SNX1 appears to direct mGluR1 into a slow recycling pathway such that in absence of SNX1, mGluR1 traffics via a faster recycling pathway. The C-terminal region of SNX1, especially the $\mathrm{H} 2$ and $\mathrm{H} 3$ domains present in the C-terminal region of SNX1 seems to be critical for the normal trafficking of mGluR1 because Hrs interacts with SNX1 through these domains. Although, we show here that the N-terminal region of SNX1 also plays critical role in the trafficking of mGluR1, the mechanism by which N-terminal region of SNX1 regulates the trafficking of group I mGluRs needs to be investigated in the future. Because SNX1 has previously been implicated in GPCR degradation, as well as in GPCR recycling, another important challenge in the future will be to elucidate how SNX1 is able to mediate these differential sorting decisions. As stated before, inappropriate trafficking of group I mGluRs could lead to improper signaling with pathological consequences. Inappropriate signaling of group I mGluRs has been suggested to be involved in the pathophysiology of multiple cognitive disorders such as Fragile X syndrome, autism, etc. Indeed, our data suggest that, in the absence of SNX1, the receptors recycle to the cell surface in an inactive form and would be unable to participate in mGluRmediated synaptic plasticity. Therefore, the SNX1-mediated recycling of these receptors through a slow recycling pathway appears to be critical for the resensitization of the receptor. Thus, our results reveal a crucial role of SNX1 in controlling the normal trafficking of group I mGluRs, failure of which could contribute to these disorders by redirecting the receptors to a wrong route. Because of these reasons, further study of the regulation of group I mGluRs by SNX1 and SNX1 interacting proteins would be of paramount importance in near future.

\section{References}

Anwyl R (2006) Induction and expression mechanisms of postsynaptic NMDA receptor-independent homosynaptic long-term depression. Prog Neurobiol 78:17-37. CrossRef Medline

Bear MF, Huber KM, Warren ST (2004) The mGluR theory of fragile X mental retardation. Trends Neurosci 27:370-377. CrossRef Medline

Bhattacharyya S (2016) Inside story of group I metabotropic glutamate receptors (mGluRs). Int J Biochem Cell Biol 77:205-212. CrossRef Medline

Bhattacharyya S, Biou V, Xu W, Schlüter O, Malenka RC (2009) A critical role for PSD-95/AKAP interactions in endocytosis of synaptic AMPA receptors. Nat Neurosci 12:172-181. CrossRef Medline

Chin LS, Raynor MC, Wei X, Chen HQ, Li L (2001) Hrs interacts with sorting nexin 1 and regulates degradation of epidermal growth factor receptor. J Biol Chem 276:7069-7078. CrossRef Medline

Choi KY, Chung S, Roche KW (2011) Differential binding of calmodulin to group I metabotropic glutamate receptors regulates receptor trafficking and signaling. J Neurosci 31:5921-5930. CrossRef Medline

Citri A, Malenka RC (2008) Synaptic plasticity: multiple forms, functions, and mechanisms. Neuropsychopharmacology 33:18-41. CrossRef Medline

Citri A, Bhattacharyya S, Ma C, Morishita W, Fang S, Rizo J, Malenka RC (2010) Calcium binding to PICK1 is essential for the intracellular retention of AMPA receptors underlying long-term depression. J Neurosci 30:16437-16452. CrossRef Medline

Conn PJ, Pin JP (1997) Pharmacology and functions of metabotropic glutamate receptors. Annu Rev Pharmacol Toxicol 37:205-237. CrossRef Medline

Cozier GE, Carlton J, McGregor AH, Gleeson PA, Teasdale RD, Mellor H, Cullen PJ (2002) The phox homology (PX) domain-dependent, 3 -phosphoinositide-mediated association of sorting nexin-1 with an early sorting endosomal compartment is required for its ability to regulate epidermal growth factor receptor degradation. J Biol Chem 277:48730 48736. CrossRef Medline

Cullen PJ (2008) Endosomal sorting and signalling: an emerging role for sorting nexins. Nat Rev Mol Cell Biol 9:574-582. CrossRef Medline

Dale LB, Babwah AV, Ferguson SS (2002) Mechanisms of metabotropic glutamate receptor desensitization: role in the patterning of effector enzyme activation. Neurochem Int 41:319-326. CrossRef Medline

Dhami GK, Ferguson SS (2006) Regulation of metabotropic glutamate receptor signaling, desensitization and endocytosis. Pharmacol Ther 111: 260-271. CrossRef Medline

Dölen G, Osterweil E, Rao BS, Smith GB, Auerbach BD, Chattarji S, Bear MF (2007) Correction of fragile X syndrome in mice. Neuron 56:955-962. CrossRef Medline

Drake MT, Shenoy SK, Lefkowitz RJ (2006) Trafficking of G proteincoupled receptors. Circ Res 99:570-582. CrossRef Medline

Ferguson SS (2001) Evolving concepts in G protein-coupled receptor endocytosis: the role in receptor desensitization and signaling. Pharmacol Rev 53:1-24. Medline

Francesconi A, Duvoisin RM (2000) Opposing effects of protein kinase C and protein kinase A on metabotropic glutamate receptor signaling: selective desensitization of the inositol trisphosphate/ $\mathrm{Ca}^{2+}$ pathway by phosphorylation of the receptor-G protein-coupling domain. Proc Natl Acad Sci U S A 97:6185-6190. CrossRef Medline

Gladding CM, Fitzjohn SM, Molnár E (2009) Metabotropic glutamate receptor-mediated long-term depression: molecular mechanisms. Pharmacol Rev 61:395-412. CrossRef Medline

Grant BD, Donaldson JG (2009) Pathways and mechanisms of endocytic recycling. Nat Rev Mol Cell Biol 10:597-608. CrossRef Medline

Gulia R, Sharma R, Bhattacharyya S (2017) A critical role for ubiquitination in the endocytosis of glutamate receptors. J Biol Chem 292:1426-1437. CrossRef Medline

Gullapalli A, Garrett TA, Paing MM, Griffin CT, Yang Y, Trejo J (2004) A role for sorting nexin 2 in epidermal growth factor receptor down-regulation: evidence for distinct functions of sorting nexin 1 and 2 in protein trafficking. Mol Biol Cell 15:2143-2155. CrossRef Medline

Heydorn A, Søndergaard BP, Ersbøll B, Holst B, Nielsen FC, Haft CR, Whistler J, Schwartz TW (2004) A library of 7TM receptor C-terminal tails: interactions with the proposed post-endocytic sorting proteins ERMbinding phosphoprotein 50 (EBP50), $\mathrm{N}$-ethylmaleimide-sensitive factor (NSF), sorting nexin 1 (SNX1), and G protein-coupled receptor- 
associated sorting protein (GASP). J Biol Chem 279:54291-54303. CrossRef Medline

Huber KM, Gallagher SM, Warren ST, Bear MF (2002) Altered synaptic plasticity in a mouse model of fragile X mental retardation. Proc Natl Acad Sci U S A 99:7746-7750. CrossRef Medline

Iacovelli L, Salvatore L, Capobianco L, Picascia A, Barletta E, Storto M, Mariggiò S, Sallese M, Porcellini A, Nicoletti F, De Blasi A (2003) Role of G protein-coupled receptor kinase 4 and beta-arrestin 1 in agoniststimulated metabotropic glutamate receptor 1 internalization and activation of mitogen-activated protein kinases. J Biol Chem 278:12433-12442. CrossRef Medline

Kim CH, Lee J, Lee JY, Roche KW (2008) Metabotropic glutamate receptors: phosphorylation and receptor signaling. J Neurosci Res 86:1-10. CrossRef Medline

Koekkoek SK, Yamaguchi K, Milojkovic BA, Dortland BR, Ruigrok TJ, Maex R, De Graaf W, Smit AE, VanderWerf F, Bakker CE, Willemsen R, Ikeda T, Kakizawa S, Onodera K, Nelson DL, Mientjes E, Joosten M, De Schutter E, Oostra BA, Ito M, De Zeeuw CI (2005) Deletion of FMR1 in Purkinje cells enhances parallel fiber LTD, enlarges spines, and attenuates cerebellar eyelid conditioning in fragile X syndrome. Neuron 47:339-352. CrossRef Medline

Komada M, Kitamura N (1995) Growth factor-induced tyrosine phosphorylation of Hrs, a novel 115-kilodalton protein with a structurally conserved putative zinc finger domain. Mol Cell Biol 15:6213-6221. CrossRef Medline

Komada M, Masaki R, Yamamoto A, Kitamura N (1997) Hrs, a tyrosine kinase substrate with a conserved double zinc finger domain, is localized to the cytoplasmic surface of early endosomes. J Biol Chem 272:2053820544. CrossRef Medline

Kouranti I, Sachse M, Arouche N, Goud B, Echard A (2006) Rab35 regulates an endocytic recycling pathway essential for the terminal steps of cytokinesis. Curr Biol 16:1719-1725. CrossRef Medline

Kurten RC, Cadena DL, Gill GN (1996) Enhanced degradation of EGF receptors by a sorting nexin, SNX1. Science 272:1008-1010. CrossRef Medline

Kwong J, Roundabush FL, Hutton Moore P, Montague M, Oldham W, Li Y, Chin LS, Li L (2000) Hrs interacts with SNAP-25 and regulates $\mathrm{Ca}^{2+}$ dependent exocytosis. J Cell Sci 113:2273-2284. Medline

Mahato PK, Pandey S, Bhattacharyya S (2015) Differential effects of protein phosphatases in the recycling of metabotropic glutamate receptor 5 . Neuroscience 306:138-150. CrossRef Medline

Maxfield FR, McGraw TE (2004) Endocytic recycling. Nat Rev Mol Cell Biol 5:121-132. CrossRef Medline

Michalon A, Sidorov M, Ballard TM, Ozmen L, Spooren W, Wettstein JG, Jaeschke G, Bear MF, Lindemann L (2012) Chronic pharmacological mGlu5 inhibition corrects fragile $\mathrm{X}$ in adult mice. Neuron 74:49-56. CrossRef Medline

Mundell SJ, Matharu AL, Pula G, Roberts PJ, Kelly E (2001) Agonistinduced internalization of the metabotropic glutamate receptor $1 \mathrm{a}$ is arrestin- and dynamin-dependent. J Neurochem 78:546-551. CrossRef Medline

Mundell SJ, Pula G, McIlhinney RA, Roberts PJ, Kelly E (2004) Desensitization and internalization of metabotropic glutamate receptor la following activation of heterologous $\mathrm{Gq} / 11$-coupled receptors. Biochemistry 43: 7541-7551. CrossRef Medline

Nakanishi S (1994) Metabotropic glutamate receptors: synaptic transmission, modulation, and plasticity. Neuron 13:1031-1037. CrossRef Medline

Nisar S, Kelly E, Cullen PJ, Mundell SJ (2010) Regulation of P2Y1 receptor traffic by sorting nexin 1 is retromer independent. Traffic 11:508-519. CrossRef Medline

Pandey S, Mahato PK, Bhattacharyya S (2014) Metabotropic glutamate receptor 1 recycles to the cell surface in protein phosphatase 2A-dependent manner in non-neuronal and neuronal cell lines. J Neurochem 131:602614. CrossRef Medline

Pin JP, Duvoisin R (1995) The metabotropic glutamate receptors: structure and functions. Neuropharmacology 34:1-26. CrossRef Medline

Sallese M, Salvatore L, D’Urbano E, Sala G, Storto M, Launey T, Nicoletti F, Knöpfel T, De Blasi A (2000) The G-protein-coupled receptor kinase GRK4 mediates homologous desensitization of metabotropic glutamate receptor 1. FASEB J 14:2569-2580. CrossRef Medline

Sato M, Sato K, Liou W, Pant S, Harada A, Grant BD (2008) Regulation of endocytic recycling by $C$. elegans Rab35 and its regulator RME-4, a coated-pit protein. EMBO J 27:1183-1196. CrossRef Medline

Schnabel R, Kilpatrick IC, Collingridge GL (2001) Protein phosphatase inhibitors facilitate DHPG-induced LTD in the CA1 region of the hippocampus. Br J Pharmacol 132:1095-1101. CrossRef Medline

Schneider CA, Rasband WS, Eliceiri KW (2012) NIH image to ImageJ: 25 years of image analysis. Nat Methods 9:671-675. CrossRef Medline

Sorkin A, von Zastrow M (2009) Endocytosis and signalling: intertwining molecular networks. Nat Rev Mol Cell Biol 10:609-622. CrossRef Medline

Trivedi RR, Bhattacharyya S (2012) Constitutive internalization and recycling of metabotropic glutamate receptor 5 (mGluR5). Biochem Biophys Res Commun 427:185-190. CrossRef Medline

van der Sluijs P, Hull M, Webster P, Mâle P, Goud B, Mellman I (1992) The small GTP-binding protein rab4 controls an early sorting event on the endocytic pathway. Cell 70:729-740. CrossRef Medline

Wang Y, Zhou Y, Szabo K, Haft CR, Trejo J (2002) Down-regulation of protease-activated receptor-1 is regulated by sorting nexin 1 . Mol Biol Cell 13:1965-1976. CrossRef Medline

Wassmer T, Attar N, Bujny MV, Oakley J, Traer CJ, Cullen PJ (2007) A loss-of-function screen reveals SNX5 and SNX6 as potential components of the mammalian retromer. J Cell Sci 120:45-54. CrossRef Medline

Wassmer T, Attar N, Harterink M, van Weering JR, Traer CJ, Oakley J, Goud B, Stephens DJ, Verkade P, Korswagen HC, Cullen PJ (2009) The retromer coat complex coordinates endosomal sorting and dynein-mediated transport, with carrier recognition by the trans-golgi network. Dev Cell 17:110-122. CrossRef Medline

Worby CA, Dixon JE (2002) Sorting out the cellular functions of sorting nexins. Nat Rev Mol Cell Biol 3:919-931. CrossRef Medline

Yudowski GA, Puthenveedu MA, Henry AG, von Zastrow M (2009) Cargomediated regulation of a rapid Rab4-dependent recycling pathway. Mol Biol Cell 20:2774-2784. CrossRef Medline

Zhong Q, Lazar CS, Tronchère H, Sato T, Meerloo T, Yeo M, Songyang Z, Emr SD, Gill GN (2002) Endosomal localization and function of sorting nexin 1. Proc Natl Acad Sci U S A 99:6767-6772. CrossRef Medline 